\title{
The Effect of Lutein on Eye and Extra-Eye Health
}

\author{
Silvio Buscemi ${ }^{1, *}\left(\mathbb{C}\right.$, Davide Corleo ${ }^{1}\left(\mathbb{D}\right.$, Francesco Di Pace $^{2}$, Maria Letizia Petroni ${ }^{3}$, \\ Angela Satriano ${ }^{4}$ and Giulio Marchesini ${ }^{3}$ (D)
}

1 Dipartimento Biomedico di Medicina Interna e Specialistica (DIBIMIS), University of Palermo, Unit of Endocrinologia, Malattie del Ricambio e Della Nutrizione, Policlinico University Hospital, 90127 Palermo, Italy; davidecorleo@gmail.com

2 Dipartimento di Biomedicina Sperimentale e Neuroscienze Cliniche (BIONEC), University of Palermo, Unit of Oculistica, Policlinico University Hospital, 90127 Palermo, Italy; francesco.dipace@unipa.it

3 Dipartimento di Scienze Mediche e Chirurgiche, University of Bologna, SSD di Malattie del Metabolismo e Dietetica Clinica, S. Orsola-Malpighi University Hospital, 40135 Bologna, Italy; marialetizia.petroni@gmail.com (M.L.P.); giulio.marchesini@unibo.it (G.M.)

4 IRCCS Policlinico San Donato, 20097 San Donato Milanese, Italy; angela.satriano@gmail.com

* Correspondence: silvio.buscemi@unipa.it

Received: 5 August 2018; Accepted: 16 September 2018; Published: 18 September 2018

check for updates

\begin{abstract}
Lutein is a carotenoid with reported anti-inflammatory properties. A large body of evidence shows that lutein has several beneficial effects, especially on eye health. In particular, lutein is known to improve or even prevent age-related macular disease which is the leading cause of blindness and vision impairment. Furthermore, many studies have reported that lutein may also have positive effects in different clinical conditions, thus ameliorating cognitive function, decreasing the risk of cancer, and improving measures of cardiovascular health. At present, the available data have been obtained from both observational studies investigating lutein intake with food, and a few intervention trials assessing the efficacy of lutein supplementation. In general, sustained lutein consumption, either through diet or supplementation, may contribute to reducing the burden of several chronic diseases. However, there are also conflicting data concerning lutein efficacy in inducing favorable effects on human health and there are no univocal data concerning the most appropriate dosage for daily lutein supplementation. Therefore, based on the most recent findings, this review will focus on lutein properties, dietary sources, usual intake, efficacy in human health, and toxicity.
\end{abstract}

Keywords: lutein; carotenoids; antioxidants; eye health; age-related macular degeneration; cataract; cardiovascular health; cognitive performances; cancer

\section{Introduction}

A large body of evidence suggests that a diet rich in antioxidants, which have an anti-inflammatory role [1,2], may contribute to reducing the burden of chronic diseases [3]. Carotenoids are nutrients widely distributed in foods, especially in fruit and vegetables [4], and appear to have antioxidant properties $[5,6]$. In recent decades, there has been increasing interest in their effects on health; a high dietary intake of carotenoids has been associated with beneficial effects in several systemic diseases [7] and in eye disorders, with protection of the retina from phototoxic light damage [8]. Most studies have focused on lutein (L), a carotenoid with a strong antioxidant effect in vitro [9] that has been associated with a reduced risk of age-related diseases [10]. Lutein is a xanthophyll, i.e., an oxygenated carotenoid that all mammalians, humans included, derive from their diet because they are unable to synthesize carotenoids [11]. Several studies have shown that high L intake, either through diet or as nutritional supplement, has beneficial effects on eye diseases, preventing or even improving both age-related macular degeneration (AMD) [12-16] and cataract [17-21]. However, conflicting 
data had been reported concerning L efficacy [22-30], and in 2006, it was claimed that no compelling evidence had been provided concerning the supposed beneficial effect of $L$ on human health [31]. Furthermore, no univocal data concerning the appropriate dosage for possible L supplementation had been found [32-38]. More recently, a number of studies have suggested that L may indeed have favorable effects via anti-inflammatory activity [39], improving cognitive functions [40], and decreasing the risk of cancer [41], cardiovascular diseases [39] and other systemic conditions [42-44]. Overall, it seems that the amount of L intake, including by supplementation, may partly counter inflammatory processes and favor human health, but inconsistencies still remain.

We reviewed the literature on the evidence for the health effects of $\mathrm{L}$, including its usual intake with different diets, adequate doses, and safety of supplementation, with specific reference to eye diseases.

\section{Characteristics of Lutein}

\subsection{Structure and Distribution}

The structure of $\mathrm{L}$ is similar to that of other carotenoids, with a skeleton made up of 40 carbon atoms, organized into eight isoprene units [45], as shown in Figure 1. However, an important chemical difference with functional implications is the presence of two oxygen atoms inside the structure [46], thus making L a polar carotenoid which is classified as a xanthophyll, namely an oxygenated carotenoid. With zeaxanthin (Z), another xanthophyll, $\mathrm{L}$ is the main carotenoid in the human macula [45], so that the two compounds are mostly referred to as macular pigments (MP). Lutein is found mainly in the inner plexiform layer and in Henle's fiber layer [47] but it can also be found in Müller cells [48]. The presence of $L$ has also been demonstrated in peripheral regions of the fovea [49], but its content decreases in the central region where $Z$ is prevalent [49] by a 2:1 ratio [50]. Interestingly, the content of carotenoids diminishes significantly, by a factor of 100, moving away from the macula [51]. In infants, the macular levels of $\mathrm{L}$ are higher than those of $\mathrm{Z}$, probably due to differences in transport mechanisms that are not yet completely developed [49]. On the other hand, Bernstein et al. reported that uveal structures account for about $50 \%$ of total eye carotenoids and $30 \%$ of total eye L [52]; this is the basis for the possible beneficial effects that L may have in the ciliary body and in the iris. Sato et al. suggested that $\mathrm{L}$ uptake in the retina may be mediated by a specific transporter, namely scavenger class B type 1 [53], thus explaining the massive build-up of L in the eye. Finally, L is significantly detectable not only in the eye, but also in brain, where it represents the main carotenoid, especially in infants [54] and in the elderly [55].<smiles>CC1=C[C@@H](O)CC(C)(C)[C@H]1/C=C/C(C)=C/C=C/C(C)=C/C=C/C=C(C)/C=C/C=C(C)/C=C/C1=C(C)C[C@@H](O)CC1(C)C</smiles>

Figure 1. Structure of lutein.

\subsection{Absorption and Metabolism}

As reported above, mammalians are not able to synthesize carotenoids which therefore need to be introduced with food [11]. Once ingested, L is absorbed by the mucosa of the small bowel and bound to chylomicrons; then, it is secreted into lymph and reaches the liver [56]. In hepatocytes, $\mathrm{L}$ is incorporated into lipoproteins that are distributed to peripheral tissues $[57,58]$, particularly the retina, where the highest concentrations have been demonstrated [59]. L is fat-soluble [60], hence the dietary content of lipids mediates L absorption through its incorporation into micelles [61], and several dietary factors may compete. A diet rich in fiber has been reported to reduce carotenoid serum levels $[62,63]$, also affecting L absorption, whereas the presence of other carotenoids in diet might interfere with 
L assimilation, probably via a competitive mechanism [64]. The content of iron and zinc as well as protein deficiency may affect $\mathrm{L}$ absorption [65]; conversely, the presence of mono- and di-glycerides is likely to positively regulate L absorption, as suggested by significantly increased L plasma levels [66]. Finally, extra-dietary factors may reduce L bioavailability. Orlistat, a drug that inhibits lipase activity, has proven to decrease L absorption [67] to an extent similar to that of impaired activity of pancreatic enzymes [68], as in the case of in vitro measurements relative to patients with cystic fibrosis [69] or, to a lesser extent, with smoking [70] and alcohol consumption [71].

\subsection{Mechanisms of Action}

Both animal and in vitro studies demonstrated that some carotenoids are compounds with antioxidant activity [5,6]. Lutein has been demonstrated to exert an extremely potent antioxidant action by quenching singlet oxygen and scavenging free radicals [9,72], although it seems to be less potent than Z [9]. Another protective effect of L consists in the ability of filtering blue light, thus reducing phototoxic damage to photoreceptor cells [73]. Subczynski et al. hypothesized that L properties might be amplified by its localization in the most vulnerable regions of the retina and by the specific orientation in membranes [74]. Notably, several studies have observed that L inhibits both the pro-inflammatory cytokine cascade [39] and the transcription factor nuclear factor-kB (NF-kB) [75-77]. There is also compelling evidence that L reduces reactive oxygen species (ROS) production [75,78], the expression of inducible nitric oxide synthase (iNOS) [79] and the activation of the complement system [80]. Through all these mechanism(s), it is quite conceivable that $\mathrm{L}$ may exert a pivotal role in regulating immune pathways, modulating inflammatory responses, and reducing oxidative damage.

\section{Dietary Lutein Intake}

Lutein is naturally abundant and available in fruit, cereals, and vegetables, and it is also present in egg yolk [4], as seen in Table 1, where its bioavailability is higher than in any other food [81]. Since L intake depends on vegetable consumption, it may vary according to dietary habits, in a range that has been estimated from $0.67 \mathrm{mg} / \mathrm{d}$ to more than $20 \mathrm{mg} / \mathrm{d}$ [82]. In individuals consuming a Western-style diet, the average daily $\mathrm{L}$ intake has been estimated at $1.7 \mathrm{mg} / \mathrm{d}$ [83] while in countries that consume a Mediterranean diet rich in fruit and vegetables it has been reported to be between 1.07 [84] and $2.9 \mathrm{mg} / \mathrm{d}$ [85], with large inter-country variability. In a Korean population, the average L intake was estimated at about $3 \mathrm{mg} / \mathrm{d}$ [86]. Interestingly, the highest L intake was reported in Pacific countries, where individuals consume a diet extremely rich in fruit and vegetables, reaching the peak of about $25 \mathrm{mg} / \mathrm{d}$ in the Fiji Islands [87].

Table 1. Lutein and zeaxanthin content of some fresh foods (mean serving) a ${ }^{a}$

\begin{tabular}{ccccc}
\hline \multirow{2}{*}{ Food } & L + Z Content $(\mathbf{m g} / \mathbf{1 0 0}$ g of Food) & \multicolumn{2}{c}{$\mathbf{L}+\mathbf{Z}$ Content (mg/Household) } \\
\cline { 2 - 5 } & Raw & Cooked & Raw & Cooked \\
\hline Paprika & 18.94 & & $0.43^{\mathrm{t}}$ & \\
Sweet potato leaves & 14.72 & 11.45 & $5.15^{\mathrm{c}}$ & $7.32^{\mathrm{c}}$ \\
Dandelion & 13.61 & 9.16 & $7.48^{\mathrm{c}}$ & $9.61^{\mathrm{c}}$ \\
Pepper & 13.16 & & $0.23^{\mathrm{t}}$ & \\
Turnip greens & 12.83 & 8.44 & $7.05^{\mathrm{c}}$ & $12.15^{\mathrm{c}}$ \\
Cress & 12.50 & 8.40 & $6.25^{\mathrm{c}}$ & $11.34^{\mathrm{c}}$ \\
Spinach & 12.20 & 11.31 & $3.66^{\mathrm{c}}$ & $20.35^{\mathrm{c}}$ \\
Chard & 11.00 & 11.02 & $3.96^{\mathrm{c}}$ & $19.28^{\mathrm{c}}$ \\
Chicory & 10.30 & & $2.99^{\mathrm{c}}$ & \\
Radicchio & 8.83 & & $3.53^{\mathrm{c}}$ & \\
Kale & 6.26 & 4.98 & $1.32^{\mathrm{c}}$ & $5.88^{\mathrm{c}}$ \\
Basil & 5.65 & & $0.14^{1}$ & \\
Parsley & 5.56 & & $3.34^{\mathrm{c}}$ & \\
Collards & 4.32 & 6.2 & $1.56^{\mathrm{c}}$ & $11.77^{\mathrm{c}}$ \\
\hline
\end{tabular}


Table 1. Cont.

\begin{tabular}{ccccc}
\hline \multirow{2}{*}{ Food } & \multicolumn{2}{c}{ L + Z Content $(\mathbf{m g} / \mathbf{1 0 0} \mathbf{g}$ of Food) } & \multicolumn{2}{c}{$\mathbf{L}+\mathbf{Z}$ Content $\mathbf{( m g / H o u s e h o l d )}$} \\
\cline { 2 - 5 } & Raw & Cooked & Raw & Cooked \\
\hline Mustard greens & 3.73 & 10.4 & $2.09^{\mathrm{c}}$ & $14.56^{\mathrm{c}}$ \\
Arugula & 3.56 & & & \\
Peas & 2.48 & 2.59 & $3.59^{\mathrm{c}}$ & $4.15^{\mathrm{c}}$ \\
Lettuce & 2.31 & & $1.09^{\mathrm{c}}$ & \\
Squash & 2.13 & 2.25 & $2.40^{\mathrm{c}}$ & $4.05^{\mathrm{c}}$ \\
Egg yolk & 1.09 & & $0.19^{\mathrm{e}}$ & \\
\hline
\end{tabular}

${ }^{\mathrm{a}}$ [88]; L, lutein; Z, zeaxanthin; ${ }^{\mathrm{c}}$ cup; ${ }^{\mathrm{e}} 1$ large egg; ${ }^{1} 5$ leaves; ${ }^{\mathrm{t}} 1$ teaspoon; L.

\section{Lutein and Eye Disturbances}

\subsection{Age-Related Macular Degeneration}

Age-related macular degeneration (AMD) is the main cause of vision impairment and blindness in developed countries $[89,90]$. Low habitual consumption of green leafy vegetables and fruit is one of the risk factors of AMD [91]. To date, many studies have observed positive effects of $\mathrm{L}$ in terms of improvement of macular pigment optical density (MPOD) levels [12,14,16,32,34-38,92-100], visual acuity (VA) $[12,15,33,35,95,101,102]$ and contrast sensitivity (CS) $[12,24,33,36,37,93,95,96,99,100,102]$. The original studies that first investigated a possible protective role of $\mathrm{L}$ against AMD date back to the early 1990s. In a case-control study including 421 individuals with neovascular AMD and 615 controls, it was found that the odds ratio (OR) of developing AMD was 0.3 when the highest quintile of $\mathrm{L}$ serum concentrations was compared with the lowest quintile, hypothesizing a negative relationship between L levels and AMD risk [103]. In the same cohort, the dietary L intake was associated with the risk of $A M D$, and again an OR of 0.43 was observed comparing the highest vs. the lowest quintile of dietary L intake [10]. Following these observational studies, the efficacy of nutritional supplementation with L was investigated in intervention studies. The Lutein Antioxidant Supplementation Trial (LAST) included 90 individuals with atrophic AMD and demonstrated a significant beneficial effect of $\mathrm{L}$ supplementation $(10 \mathrm{mg} / \mathrm{d})$, either alone or in combination with other antioxidants, for nearly 1 year [12]; in particular, it was observed that L enhanced MPOD, also improving VA and CS [12]. The Carotenoids and Antioxidants in Age-Related Maculopathy Italian Study (CARMIS) demonstrated that L supplementation (10 mg/d for 1 year) in people with non-advanced AMD improved the dysfunction in the central retina assessed by multifocal electroretinograms, obtaining benefits also in terms of VA and glare sensitivity [13]. According to a more recent study, L supplementation $(20 \mathrm{mg} / \mathrm{d}$ for 3 months, followed by $10 \mathrm{mg} / \mathrm{d}$ for another 3 months) significantly increased MPOD by about $28 \%$ compared to placebo in 126 participants with AMD [14]. The Carotenoids with Co-antioxidants in Age-Related Maculopathy (CARMA) study demonstrated that L (12 mg/d for 2 years) improved VA in 433 patients with early AMD [15]. Furthermore, in the Combination of Lutein Effects in the Aging Retina (CLEAR) study, the MPOD of 72 patients with AMD significantly increased after one year of L supplementation $(10 \mathrm{mg} / \mathrm{d})$ [16].

The Age-Related Eye Disease Study 2 (AREDS2) is the most important and recent randomized controlled trial (RCT) to have assessed AMD treatment with oral supplementation of vitamins and micronutrients, including L. The original AREDS oral supplementation had already proven its efficacy in reducing the risk of developing advanced AMD [104]. In order to analyze the effect of adding $\mathrm{L}(10 \mathrm{mg} / \mathrm{d})$ and $\mathrm{Z}(2 \mathrm{mg} / \mathrm{d})$ to the original formulation [vitamin C (500 mg), vitamin E (400 IU), beta-carotene $(15 \mathrm{mg})$, zinc $(80 \mathrm{mg})$, and copper $(2 \mathrm{mg})]$, the AREDS2 study included more than 4000 individuals at risk of developing late AMD. The trial failed to prove the efficacy of $\mathrm{L}$ in reducing the progression to advanced AMD or in improving VA [27]. However, a $26 \%$ reduction of risk for late AMD was observed in individuals in the lowest quintile of $L$ dietary intake who also received AREDS2 
supplementation [105], especially in subjects with large drusen. In this study other formulations were also investigated. The AREDS formulation $+\mathrm{L}$, with and without beta-carotene, was compared to the original AREDS formulation, because of the possible increased risk of lung cancer associated with beta-carotene consumption, especially in smokers [106,107]; AMD progression was significantly reduced in the $\mathrm{L}$ enriched group, suggesting that $\mathrm{L}$ might replace beta-carotene, improving treatment safety [105].

Genetic factors are thought to influence the risk of AMD, in particular mutations involving genes encoding complement factor $\mathrm{H}$ (CFH). Interestingly, Ho et al. [108] demonstrated that higher antioxidant and L intakes significantly decreased the risk of developing AMD in individuals with CFH genes variants, probably neutralizing the augmented genetic risk. Two recent meta-analyses including L randomized clinical trials (RCTs) demonstrated beneficial effects of L on MPOD [32] and VA [33] development. However, other studies failed to demonstrate that L supplementation was able to improve both VA [14,16,22,23,26,27,32,36,92,93,98,99] and CS [15,26]. In particular, it was also shown that $\mathrm{L}$ was ineffective in reducing the risk of developing AMD $[29,30]$ and in slowing progression to late AMD [27,92]. According to the meta-analysis by Chong et al., L was unable to diminish the risk of developing AMD [29]. These differences between the studies might be partly explained by the differing duration of L supplementation, or by differences in clinical characteristics of patients enrolled in the trial protocols. Therefore, though many studies concluded that L may be able to prevent or treating AMD, additional RCTs are needed to elucidate and characterize the therapeutic properties of L. A list of the intervention studies that have assessed the effect of $\mathrm{L}$ on visual performance is presented in Table 2.

Similarly, the issue of the most appropriate dosage for L supplementation is unsolved. According to three studies, L supplementation with $20 \mathrm{mg} / \mathrm{d}$ was not more effective than the dose of $10 \mathrm{mg} / \mathrm{d}$ in improving visual performance [34-36]. Similar results were also obtained by a meta-analysis of 5 RCTs [32]. Conversely, other studies were consistent with a linear dose-response pattern for L efficacy [37,38], supported by a meta-analysis of 8 RCTs [33], suggesting that the higher the L intake, the better the outcome. These conflicting results very likely stem from differences in the study population with specific reference to dietary intake. More than 20 years ago Seddon et al. reported that a $\mathrm{L}$ intake of at least $6 \mathrm{mg} / \mathrm{d}$ was protective against AMD [10] and AREDS2 showed that the population in the lowest quintile of dietary intake (with a median consumption of only $0.7 \mathrm{mg} / \mathrm{d}$ per $1000 \mathrm{kcal}$ of energy) had the most positive results from L supplementation [105]. Therefore, in the presence of an insufficient average intake of $\mathrm{L}$ of approximately $1.4 \mathrm{mg} / \mathrm{d}$, supplementation of $10 \mathrm{mg} / \mathrm{d}$, as in the AREDS2, might be the most appropriate dosage for chronic L supplementation. 
Table 2. Intervention studies on the effects of lutein on visual performance.

\begin{tabular}{|c|c|c|c|}
\hline Study (year) & Design (Number of Participants) & Intervention and Lutein Supplementation & Effects \\
\hline AREDS2 (2013) [27] & $\begin{array}{l}\text { RCT, participants with bilateral drusen or } \\
\text { AMD in 1 eye (4176); } 4 \text { groups: G1 (1007); G2 } \\
\text { (1038); G3 (1062); G4 (1069) }\end{array}$ & $\begin{array}{c}\text { G1: AREDS formulation; } \\
\text { G2: AREDS + L } 10 \mathrm{mg}+\mathrm{Z} 2 \mathrm{mg} ; \\
\text { G3: AREDS + DHA } 350 \mathrm{mg}+\text { EPA } 650 \mathrm{mg} \\
\text { G4: AREDS + L } 10 \mathrm{mg}+\mathrm{Z} 2 \mathrm{mg}+\text { DHA } 350 \mathrm{mg}+ \\
\text { EPA } 650 \mathrm{mg}\end{array}$ & $\begin{array}{l}\text { No effect in reducing progression to advanced } \\
\text { AMD. No effect in improving VA. In the lowest } \\
\text { quintile of } L \text { dietary intake, } L+Z \text { had significant } \\
\text { effect vs. no } L+Z \text { in reducing progression to } \\
\text { advanced AMD. }\end{array}$ \\
\hline AREDS2 (2014) [105] & $\begin{array}{l}\text { RCT, participants with bilateral drusen or } \\
\text { AMD in } 1 \text { eye ( } 3335 \text { eyes analyzed); } 3 \text { groups: } \\
\text { G1 (1114 eyes); G2 (1104 eyes); G3 (1117 eyes) }\end{array}$ & $\begin{array}{l}\text { G1: AREDS + L } 10 \mathrm{mg}+\mathrm{Z} 2 \mathrm{mg} \text { without } \\
\text { beta-carotene; } \\
\text { G2: AREDS + L } 10 \mathrm{mg}+\mathrm{Z} 2 \mathrm{mg} \\
\text { G3: AREDS formulation }\end{array}$ & $\begin{array}{c}\text { G1 (compared to G3) significantly reduced } \\
\text { progression to advanced AMD and neovascular } \\
\text { AMD, no effect for CGA. No difference between } \\
\text { G2 vs. G3. }\end{array}$ \\
\hline Akuffo et al. (2015) [92] & $\begin{array}{l}\text { Intervention trial, participants with AMD (67); } \\
3 \text { groups with different dosages }\end{array}$ & $\begin{array}{c}\text { G1: L } 20 \mathrm{mg}+\mathrm{Z} 2 \mathrm{mg} \\
\text { G2: } 10 \mathrm{mg}+\mathrm{Z} 2 \mathrm{mg}+\mathrm{MZ} 10 \mathrm{mg} \\
\text { G3: } \mathrm{L} 3 \mathrm{mg}+\mathrm{Z} 2 \mathrm{mg}+\mathrm{MZ} 17 \mathrm{mg}\end{array}$ & $\begin{array}{l}\text { After } 3 \text { years, all the groups showed a significant } \\
\text { increase in MPOD but no effects in reducing } \\
\text { progression to advanced AMD or improving VA. } \\
\text { CS significantly increased, mainly in G3. }\end{array}$ \\
\hline Beatty et al. (2013) [15] & $\begin{array}{l}\text { RCT, participants with at least bilateral early } \\
\text { AMD (433); intervention group (216) vs. } \\
\text { placebo (217) }\end{array}$ & Intervention group: formulation containing L $12 \mathrm{mg}$ & $\begin{array}{l}\text { No significant improvement in CS. Significant VA } \\
\text { enhancement not before } 24 \text { months. }\end{array}$ \\
\hline Berrow et al. (2013) [26] & $\begin{array}{l}\text { RCT, participants with AMD (14); treatment } \\
\text { group (8) vs. no treatment (6) }\end{array}$ & Treatment group: L $12 \mathrm{mg}$ & $\begin{array}{l}\text { After } 40 \text { weeks, no clinical effects; only minimal } \\
\text { improvement in mfEGR. }\end{array}$ \\
\hline Bone (2010) [38] & $\begin{array}{l}\text { Intervention trial, healthy participants (87); } \\
4 \text { groups: G1 (10); G2 (17); G3 (22); G4 (38) }\end{array}$ & G1: placebo; G2: L 5 mg;G3: L 10 mg; G4: 20 mg & $\begin{array}{l}\text { MPOD increased in a linear, dose-dependent } \\
\text { manner. L did not increase MPOD in all the } \\
\text { participants. }\end{array}$ \\
\hline Cangemi (2007) [101] & $\begin{array}{l}\text { Intervention trial, participants with at least } 1 \\
\text { eye with dry AMD (37) }\end{array}$ & Formulation containing L $8 \mathrm{mg}$ & Significant improvement in VA after 6 months. \\
\hline Dawczynski et al. (2013) [35] & $\begin{array}{l}\text { RCT, participants with non-exudative AMD } \\
\text { (145); } 3 \text { groups: G1 (50); G2 (55); G3 (40) }\end{array}$ & $\begin{array}{l}\text { G1: L } 10 \mathrm{mg}+\mathrm{Z} 1 \mathrm{mg}+\text { DHA } 100 \mathrm{mg}+\text { EPA } 30 \mathrm{mg} ; \\
\text { G2: L } 20 \mathrm{mg}+\mathrm{Z} 2 \mathrm{mg}+\text { DHA } 200 \mathrm{mg}+\text { EPA } 60 \mathrm{mg} ; \\
\text { G3: placebo }\end{array}$ & $\begin{array}{c}\text { Significant increase in MPOD and improvement in } \\
\text { VA both in G1 and G2; MPOD decreased in G3. } \\
\text { No significant differences in MPOD accumulation } \\
\text { between G1 and G2. }\end{array}$ \\
\hline Fujimura et al. (2016) [96] & $\begin{array}{l}\text { Intervention trial, participants with at least } \\
1 \text { eye with wet AMD or early AMD (20) }\end{array}$ & $\begin{array}{l}\text { Formulation containing L } 20 \mathrm{mg}+\mathrm{Z} 1 \mathrm{mg}+\mathrm{DHA} \\
\qquad 200 \mathrm{mg}\end{array}$ & $\begin{array}{c}\text { After } 6 \text { months, significant increase in MPOD and } \\
\text { CS. Linear correlation between MPOD and serum } \\
\text { concentrations of L. }\end{array}$ \\
\hline Hammond et al. (2014) [97] & $\begin{array}{l}\text { RCT, healthy participants (115); intervention } \\
\text { group (58) vs. placebo (57) }\end{array}$ & $\begin{array}{l}\text { Intervention group: formulation containing } \mathrm{L} 10 \mathrm{mg} \\
\qquad+\mathrm{Z} 2 \mathrm{mg}\end{array}$ & $\begin{array}{l}\text { After } 1 \text { year, significant increase in MPOD, } \\
\text { recovery from photostress and chromatic contrast. }\end{array}$ \\
\hline Huang et al. (2015) [94] & $\begin{array}{l}\text { RCT, participants with early AMD (108); } \\
4 \text { groups: G1 (28); G2 (26); G3 (27); G4 (27) }\end{array}$ & $\begin{array}{l}\text { G1: placebo; G2: L } 10 \mathrm{mg} \text {; } \\
\text { G3: L } 20 \mathrm{mg} \text {; G4: L } 10 \mathrm{mg}+\mathrm{Z} 10 \mathrm{mg}\end{array}$ & $\begin{array}{l}\text { After } 2 \text { years, significant increase in MPOD and } \\
\text { mean retinal sensitivity. }\end{array}$ \\
\hline
\end{tabular}


Table 2. Cont.

\begin{tabular}{|c|c|c|c|}
\hline Study (year) & Design (Number of Participants) & Intervention and Lutein Supplementation & Effects \\
\hline Huang et al. (2015) [36] & $\begin{array}{l}\text { RCT, participants with early AMD (108); } \\
4 \text { groups: G1 (28)]; G2 (26); G3 (27); G4 (27) }\end{array}$ & $\begin{array}{l}\text { G1: placebo; G2: L } 10 \text { mg; } \\
\text { G3: L } 20 \text { mg; G4: L } 10 \mathrm{mg}+\text { Z } 10 \mathrm{mg}\end{array}$ & $\begin{array}{c}\text { After } 2 \text { years, significant increase in MPOD and } \\
\text { CS, no effect in VA and flash recovery time. Same } \\
\text { efficacy in all treatment groups. }\end{array}$ \\
\hline Ma et al. (2009) [23] & $\begin{array}{l}\text { Intervention trial, healthy participants (37); } \\
3 \text { groups: G1 (12); G2 (12); G3 (13) }\end{array}$ & $\begin{array}{l}\text { G1: placebo; } \\
\text { G2: L } 6 \mathrm{mg} ; \\
\text { G3: L } 12 \mathrm{mg}\end{array}$ & $\begin{array}{c}\text { After } 12 \text { weeks, no effect in improving VA and } \\
\text { glare sensitivity. CS significantly increased in both } \\
\text { G2 and G3, but much more in G3. }\end{array}$ \\
\hline Ma et al. (2012) [37] & $\begin{array}{l}\text { RCT, participants with early AMD (108); } \\
4 \text { groups: G1 (27); G2 (27); G3 (27); G4 (27); } \\
\text { group of healthy controls (36) }\end{array}$ & $\begin{array}{c}\text { G1: placebo; } \\
\text { G2: L } 10 \mathrm{mg} ; \\
\text { G3: L } 20 \mathrm{mg} ; \\
\text { G4: L } 10 \mathrm{mg}+\mathrm{Z} 10 \mathrm{mg}\end{array}$ & $\begin{array}{c}\text { After } 48 \text { weeks, both G3 and G4 effectively } \\
\text { increased MPOD; CS only improved on G3. } \\
\text { Positive correlation between MPOD increase, VA } \\
\text { and CS. Significant dose-response effect following } \\
\text { L supplementation. }\end{array}$ \\
\hline Murray et al. (2013) [16] & $\begin{array}{l}\text { RCT, participants with early AMD (72); } \\
\text { intervention group (36) vs. placebo (36) }\end{array}$ & Intervention group: formulation containing L $10 \mathrm{mg}$ & $\begin{array}{l}\text { Significant effect on MPOD. No improvement in } \\
\text { VA, but VA decreased on placebo. Changes in VA } \\
\text { were significant between L and placebo. }\end{array}$ \\
\hline Nolan et al. (2011) [98] & $\begin{array}{l}\text { RCT, healthy participants (121); intervention } \\
\text { group (61) vs. placebo (60) }\end{array}$ & $\begin{array}{l}\text { Intervention group: formulation containing } \\
\qquad \mathrm{L} 12 \mathrm{mg}+\mathrm{Z} 1 \mathrm{mg}\end{array}$ & $\begin{array}{c}\text { After } 1 \text { year, significant effect on MPOD but no } \\
\text { improvement in VA, CS, glare disability, recovery } \\
\text { from photostress. }\end{array}$ \\
\hline Obana et al. (2015) [25] & RCT, healthy participants (36) & $\mathrm{L} 10 \mathrm{mg}+\mathrm{Z} 1 \mathrm{mg}$ & $\begin{array}{l}\text { After } 6 \text { months, no effect on MPOD. Only a } \\
\text { subgroup of } 13 \text { participants had an effective } \\
\text { increase both in serum levels of L and MPOD. }\end{array}$ \\
\hline Parisi et al. (2008) [13] & $\begin{array}{l}\text { RCT, participants with non-advanced AMD } \\
\text { (27); treatment group (15) vs. no treatment [12] }\end{array}$ & $\begin{array}{l}\text { Treatment group: formulation containing } \\
\qquad \mathrm{L} 10 \mathrm{mg}+\mathrm{Z} 1 \mathrm{mg}\end{array}$ & $\begin{array}{c}\text { After } 1 \text { year, significant improvement in central } \\
\text { retina dysfunction but no effect in } \\
\text { peripheral retina. }\end{array}$ \\
\hline $\begin{array}{l}\text { Piermarocchi et al. } \\
\text { (2012) [102] }\end{array}$ & $\begin{array}{l}\text { Intervention trial, participants with dry } \\
\text { AMD [109]; treatment group [84] vs. no } \\
\text { treatment [26] }\end{array}$ & $\begin{array}{l}\text { Treatment group: formulation containing } \\
\qquad \mathrm{L} 10 \mathrm{mg}+\mathrm{Z} 1 \mathrm{mg}\end{array}$ & $\begin{array}{l}\text { Significant improvement in VA and CS after } \\
2 \text { years. }\end{array}$ \\
\hline Richer et al. (2004) [12] & $\begin{array}{l}\text { RCT, participants with atrophic AMD (90); } \\
3 \text { groups: G1 (29); G2 (30); G3 (31) }\end{array}$ & $\begin{array}{l}\text { G1: L } 10 \mathrm{mg} \text {; } \\
\text { G2: formulation containing L } 10 \mathrm{mg} \text {; G3: placebo }\end{array}$ & $\begin{array}{l}\text { After } 1 \text { year, both G1 and G2 showed significantly } \\
\text { increased MPOD, VA and CS. }\end{array}$ \\
\hline Richer et al. (2011) [95] & $\begin{array}{l}\text { RCT, participants with non-advanced AMD } \\
\text { (60); } 3 \text { groups: G1 (10); G2 (25); G3 (25) }\end{array}$ & $\begin{array}{l}\text { G1: L } 9 \text { mg; G2: Z } 8 \text { mg; } \\
\text { G3: } 19 \text { mg + Z } 8 \text { mg }\end{array}$ & $\begin{array}{l}\text { After } 1 \text { year, both G1 and G2 showed effectively } \\
\text { increased MPOD and CS; no improvement in G3. }\end{array}$ \\
\hline Rosenthal et al. (2006) [22] & $\begin{array}{l}\text { Intervention trial, participants with AMD (45); } \\
3 \text { groups: G1 (15); G2 (15)]; G3 (15) }\end{array}$ & $\begin{array}{l}\text { G1: L 2.5 mg; G2: L } 5 \text { mg; } \\
\text { G3: L } 10 \mathrm{mg}\end{array}$ & $\begin{array}{l}\text { After } 6 \text { months, no effect in VA. } 10 \mathrm{mg} \text { were safely } \\
\text { administered without toxicity or adverse events. }\end{array}$ \\
\hline $\begin{array}{l}\text { Sabour-Pickett et al. } \\
\text { (2014) [100] }\end{array}$ & $\begin{array}{l}\text { Intervention trial, participants with AMD (52); } \\
\text { 3 groups: G1 (17); G2 (21); G3 (14) }\end{array}$ & $\begin{array}{c}\text { G1: L } 20 \mathrm{mg}+\mathrm{Z} 2 \mathrm{mg} \\
\text { G2: } \mathrm{L} 10 \mathrm{mg}+\mathrm{Z} 2 \mathrm{mg}+\mathrm{MZ} 10 \mathrm{mg} \\
\text { G3: } \mathrm{L} 3 \mathrm{mg}+\mathrm{Z} 2 \mathrm{mg}+\mathrm{MZ} 17 \mathrm{mg}\end{array}$ & $\begin{array}{l}\text { After } 1 \text { year, MPOD increased in all groups; the } \\
\text { significant improvement in CS was much more } \\
\text { effective in G3. }\end{array}$ \\
\hline
\end{tabular}


Table 2. Cont.

\begin{tabular}{|c|c|c|c|}
\hline Study (year) & Design (Number of Participants) & Intervention and Lutein Supplementation & Effects \\
\hline Sasamoto et al. (2011) [24] & $\begin{array}{l}\text { Intervention trial, healthy controls (5), } \\
\text { participants with AMD (33) and participants } \\
\text { with central serous chorioretinopathy (5) }\end{array}$ & Formulation containing L $6 \mathrm{mg}$ & $\begin{array}{l}\text { After } 1 \text { year, no effect in MPOD. Significant } \\
\text { improvement in CS and retinal sensitivity. }\end{array}$ \\
\hline Stringham et al. (2016) [34] & $\begin{array}{l}\text { RCT, healthy participants (28); } 4 \text { groups: } \\
\text { G1 (5); G2 (7); G3 (8); G4 (8) }\end{array}$ & $\begin{array}{c}\text { G1: placebo; } \\
\text { G2: L } 6 \mathrm{mg}+\mathrm{Z} \text { 0,7 mg + MZ 0,5 mg; } \\
\text { G3: L } 10.9 \mathrm{mg}+\mathrm{Z} 1.3 \mathrm{mg}+\mathrm{MZ} 0.9 \mathrm{mg} \\
\text { G4: L } 22 \mathrm{mg}+\mathrm{Z} 2.7 \mathrm{mg}+\mathrm{MZ} 2 \mathrm{mg}\end{array}$ & $\begin{array}{l}\text { All the intervention groups showed a significant } \\
\text { effect in MPOD at } 12 \text { weeks, G3 was much } \\
\text { more effective. }\end{array}$ \\
\hline Weigert et al. (2011) [14] & $\begin{array}{l}\text { RCT, participants with AMD (126); } 2 \text { groups: } \\
\text { G1 (84); G2 (42) }\end{array}$ & $\begin{array}{c}\text { G1: L } 20 \mathrm{mg} \text { for the first } 3 \text { months, } \mathrm{L} 10 \mathrm{mg} \text { for the } \\
\text { last } 3 \text { ones; G2: placebo }\end{array}$ & $\begin{array}{c}\text { After } 6 \text { months, MPOD increased by nearly } 28 \% \\
\text { vs. placebo in G1. No improvement in VA and } \\
\text { macular function. The lower MPOD at baseline, } \\
\text { the greater the improvement. Linear correlation } \\
\text { between changes in MPOD, VA and } \\
\text { macular function. }\end{array}$ \\
\hline $\begin{array}{l}\text { Wolf-Schnurrbusch et al. } \\
\qquad \text { (2015) [99] }\end{array}$ & $\begin{array}{l}\text { Intervention trial, participants with AMD (79); } \\
2 \text { groups: G1 (40); G2 (39) }\end{array}$ & $\begin{array}{l}\text { G1: formulation containing L } 10 \mathrm{mg}+\mathrm{Z} 1 \mathrm{mg} \text {; } \\
\text { G2: formulation containing } \mathrm{L} 10 \mathrm{mg}+\mathrm{Z} 1 \mathrm{mg}+ \\
\text { DHA and EPA } 130 \mathrm{mg}\end{array}$ & $\begin{array}{l}\text { After } 6 \text { months and } 1 \text { year, MPOD and CS [not } \\
\text { VA] significantly increased G1. No significant } \\
\text { effect on G2. }\end{array}$ \\
\hline Yao et al. (2013) [93] & $\begin{array}{l}\text { RCT, healthy participants (120); treatment } \\
\text { group (60) vs. placebo }(60)\end{array}$ & Treatment group: L $20 \mathrm{mg}$ & $\begin{array}{l}\text { After } 1 \text { year, significant improvement in MPOD, } \\
\text { CS and glare sensitivity vs. placebo. No effect } \\
\text { in VA. }\end{array}$ \\
\hline
\end{tabular}

AMD: age-related macular degeneration; AREDS: age-related eye disease study (formulation: vit. C: $500 \mathrm{mg}$; vit. E: 400 UI; beta carotene: $15 \mathrm{mg}$; zinc: $80 \mathrm{mg}$; copper: $2 \mathrm{mg}$ ); CS: contrast sensitivity; DHA: docosahexaenoic acid; EPA: eicosapentaenoic acid; L: lutein; mfEGR: multifocal electroretinogram; MPOD: macular pigment optical density; MZ: meso-zeaxanthin;

RCT: randomized controlled trial; VA: visual acuity; Z: zeaxanthin. 


\subsection{Cataract}

Cataract, as well as AMD, is a growing health problem responsible for vision loss [110], due to oxidation of lens structures. Antioxidants, specifically L, might be a safe treatment for this condition, and in-vitro studies have demonstrated that $\mathrm{L}$ is able to prevent cataract in bovine cells by inhibiting the proliferation and migration of lens cells [111], as well as to prevent ultraviolet damage in human lens cells [109]. A few observational studies have found a significant correlation between high L plasma concentrations and a low risk for developing cataract [112-115], and a negative association has also been reported between daily $L$ intake and the risk of cataract, especially nuclear cataract [17-21]. In particular, in over 30,000 participants Brown et al. observed a significant reduction (-19\%) in the risk of cataract in the highest quintile of $\mathrm{L}$ intake compared with the lowest quintile [20]. Similar results were obtained by both Chasan-Taber et al. [21] and Moeller et al. [19]. Along this line, Olmedilla et al. demonstrated that L supplementation for 2 years $(15 \mathrm{mg} / \mathrm{d})$ was effective in improving visual function in subjects with age-related nuclear cataract [116], but these beneficial effects are controversial [117]. Lyle et al. showed that neither high L serum levels had an effect on the incidence of cataract [118], nor was there a correlation between the disease and L intake [119]. Also, the AREDS2 study showed that $\mathrm{L}$ treatment was ineffective both in preventing vision loss and in slowing progression towards cataract surgery [120]. However, a meta-analysis reported a significant negative association between $\mathrm{L}$ serum levels and risk of nuclear cataract [121] and another meta-analysis of 6 cohort studies including more than 40,000 participants concluded that daily L intake was negatively associated with the risk of developing nuclear cataract in a dose-linear response [122]. Mares-Perlman et al. suggested that these uncertainties could be explained by limitations in the studies and by the different types of cataract [123] and, irrespective of conflicting data, Weikel et al. concluded that L might be useful in cataract treatment [124]. We definitely need more data, and carefully conducted RCTs evidence on this issue consisting of prospective clinical studies that use data obtained from database of patients who had been prescribed lutein to slow the progression of cataract. The possibility to effectively treat this disabling disease with a safe nutritional intervention is a key issue and needs to be clarified.

\subsection{Other Eye Diseases}

The effect of $L$ has also been also investigated for other eye diseases, but the results have generally been unsatisfactory. A recent RCT reported that L supplementation $(10 \mathrm{mg} / \mathrm{d})$ for 36 weeks in patients with diabetic retinopathy (DR) improved only CS, without any effect on VA [125]. The Atherosclerosis Risk in Communities (ARIC) study showed that L intake was not associated with DR in spite of the marked antioxidant properties [126].

In retinitis pigmentosa, 24-week L supplementation significantly increased the visual field in one study [127], but other studies [128,129] failed to confirm this finding.

Retinopathy of prematurity (ROP) is an oxidative-based disease [130], and it has been hypothesized that $\mathrm{L}$ might be useful in managing this condition thanks to its anti-oxidant properties. A recent study in mice demonstrated that L significantly ameliorated retinal revascularization [131], but in preterm infants L failed to prevent ROP [132]. In this case as well, more research is eagerly awaited.

\section{Extra-Eye Actions}

\subsection{Cognitive Function}

Given the presence of $\mathrm{L}$ in the brain, much research has been conducted to investigate the potential of $\mathrm{L}$ in slowing down age-related cognitive decline and eventually how to recover damaged cognitive functions. Lutein is considered to have a significant role in preserving neural efficiency. In a cohort of centenarians, Johnson et al. observed that higher circulating L levels were associated with better cognitive performance [40] and similar results were also reported in the general population of older adults [133]. Higher L circulating levels have been correlated with better cognitive ability scores, as measured by the Wechsler scale [134], and it has been proposed that an increased parahippocampal 
cortex volume may account for these results. Interestingly, Picone et al. observed a positive correlation between L and blood concentrations of activin-A in infants [135], a neuroprotection marker [136,137]. In older women, Johnson et al. demonstrated that L supplementation significantly improved some cognitive functions, namely verbal fluency, memory scores and efficient learning [138]. Recent data also demonstrated that $\mathrm{L}$ is effective in improving memory [139] or other measures of cognitive function, such as spatial memory and reasoning ability [140]. By functional magnetic resonance imaging, it has been observed that L may improve cerebral perfusion [141] or neural efficiency in older adults [142] and two studies have demonstrated a relationship between MPOD and some aspects of cognitive function as prospective memory [143] or verbal fluency and processing speed [144]. Furthermore, Kuchan et al. [145] reported that L stimulates the in-vitro differentiation of human stem cells into neural progenitors, a noteworthy effect that might protect against specific types of dementia as Alzheimer's disease. In mice, $\mathrm{L}$ was able to reverse the loss of nigral dopaminergic neurons by reducing oxidative stress and improving mitochondrial dysfunction [146]. Morris et al. prospectively reported that dietary factors associated with $\mathrm{L}$ intake slow down age-related cognitive decline [147]. Despite these promising reports, the AREDS2 study did not observe any favorable effect of L on cognitive performance [148]. Given the amount of data supporting a beneficial role of $\mathrm{L}$ on brain tissue and the importance of treatments for cognitive disorders, randomized clinical trials on the possible therapeutic role of $\mathrm{L}$ should be planned.

\subsection{Cardiovascular Health}

Atherosclerosis and cardiovascular $(\mathrm{CV})$ health partly depend on the activation of inflammatory cytokines [149]; therefore, nutrients and drugs that favorably influence the cytokine cascade might effectively prevent CV damage. In guinea pigs fed with L-enriched foods a decrease in medium size low density lipoprotein (LDL) was observed [150], associated with reduced aortic cholesterol, reduced oxidized LDL, and a minimally reduced intimal thickening compared to control animals. In mice, L significantly suppressed atherosclerotic plaque formation by increasing peroxisome proliferator-activated receptor- $\alpha$ (PPAR- $\alpha)$ expression [151]. Furthermore, in rats L countered the oxidative stress induced by hyper-homocysteinemia [152], a minor CV risk factor [153,154] and prevented cardiac and renal injury induced by streptozotocin in association with reduced oxidative stress markers [155]. Interestingly, Rafi et al. observed that L significantly decreased the expression of inducible nitric oxide synthase in mice macrophage cells [79], a factor associated with inflammation and atherosclerosis [156].

Many studies in humans have also provided evidence for a beneficial role of L supplementation, lowering the blood concentrations of inflammatory cytokines, while favoring the secretion of anti-inflammatory cytokines [39]. Indeed, L reduced circulating complement factors [157,158], complement system activation [80], and factors potentially harmful to CV health [159]. Other factors influencing atherosclerosis and CV risk, like lipid peroxidation and C-reactive protein serum concentrations, were shown to be reduced following L supplementation [160]. Karppi et al. suggested that L plasma levels were inversely associated with circulating levels of oxidized LDL [161], whereas low circulating levels of $\mathrm{L}$ were associated with an increased risk of developing atrial fibrillation [162]. In patients with early atherosclerosis, L supplementation $(20 \mathrm{mg} / \mathrm{d})$ for 3 months was associated with a significant reduction in plasma LDL-cholesterol and triglycerides [163]. An RCT conducted on 144 patients with subclinical atherosclerosis demonstrated that L significantly decreased the carotid intima-media thickness [164], which is an established CV risk factor [165]. In mononuclear cells of patients with stable angina or coronary acute syndrome, L negatively regulated the expression of inflammatory cytokines such as interleukin-1b, interleukin-6, and tumor necrosis factor- $\alpha$ [39]. Interestingly, a recent study demonstrated an independent positive association between $\mathrm{L}$ plasma levels and telomere length [166], a suggested marker of the aging process and also proposed as a predictor of myocardial infarction [167]. 
On the contrary, other studies have failed to demonstrate that $\mathrm{L}$ is effective in $\mathrm{CV}$ prevention. The AREDS2 study found that L supplementation was unable to reduce CV diseases in patients with AMD [168]. Leermakers et al. assessed median L intake in 13-month-old children by administering a food frequency questionnaire to their caregivers but, at 6 years of age, they did not find any improvement in cardiometabolic health [169], suggesting a lack of correlation between L consumption and parameters of $\mathrm{CV}$ health. However, a recent meta-analysis by the same authors that included studies enrolling more than 350,000 participants concluded that L consumption is associated with better CV health [170]. Although these data have been obtained mostly from observational studies, they conclude that the risk for coronary disease and stroke is lower in the highest tertile for L intake compared to the lowest. In summary, there is some evidence that $\mathrm{L}$ is a $\mathrm{CV}$ protective factor, however, definitive data from RCTs are still missing.

\subsection{Cancer Risk}

Cancer is recognized as a multifactorial disease based not only on an uncontrolled cellular growth, but also on immune dysregulation [171] and activation of inflammatory pathways [172]. Indeed, a diet rich in fresh fruit and vegetables is generally considered a protective factor [3]; as such, L might also play a role against cancer. Slattery et al. observed a 17\% reduced risk of developing colon cancer in the highest vs. the lowest quintile of daily $\mathrm{L}$ consumption [41]; a negative correlation between $\mathrm{L}$ intake and risk of pancreatic cancer was also reported [173]; moreover, $\mathrm{L}$ appeared to be protective also against breast cancer [174-176] and head-and-neck cancer [177]. Interesting results have also come from several meta-analyses investigating the potential of $\mathrm{L}$ as an anti-cancer compound. According to Chen et al. L is associated with a decreased risk of non-Hodgkin lymphoma [178], whereas Ge et al. observed a negative association between L intake and esophageal cancer risk [179]. Interestingly, in-vitro studies with $L$ have not reported a cytotoxic effect against normal human colon cells, but a significantly reduced survival rate of colon cancer cells [180]. However, in this case as well, the results are conflicting and findings that fail to support this association have also been reported [181-184]. At present, there are too many uncertainties about the anti-cancer action of $\mathrm{L}$, but data are sufficient to pursue this research line.

\subsection{Other Systemic and Metabolic Effects}

Lutein might have an important role even in other diseases. In rats fed with high fat diet, Qiu et al. observed that L significantly decreased circulating cholesterol serum levels and hepatic cholesterol and triglycerides [185]. These authors also found that L improved insulin sensitivity by acting on the expression of key factors involved in hepatic signaling, such as sirtuin- 1 and PPAR- $\alpha$. Another experiment carried out on mice demonstrated that $L$ prevented arsenic-induced hepatotoxicity via reduced ROS production and lipid peroxidation [78]. Cao et al. reported a dose-dependent inverse association between non-alcoholic fatty liver disease risk and serum carotenoid levels, including L [43]; in particular, they observed a $44 \%$ lower risk in the highest vs. lowest quintile. Accordingly, L might also exert a significant protective action on the liver.

Similarly, L might have a beneficial effect even on lung function, and a high L intake was associated with a significant improvement in forced vital capacity and forced expiratory volume [44]. However, there is probably too little evidence to conclude on this issue [186].

Bone health is of great importance, especially in the elderly as decreased bone mineral density may lead to osteoporosis and fractures [187]. In mice, L significantly stimulated bone formation and inhibited bone reabsorption through its regulatory activity on NF- $\mathrm{KB}$ [188]. Similar results were obtained in vitro, where $\mathrm{L}$ was effective in increasing bone formation, preventing bone loss, and decreasing the interleukin-1-dependent differentiation of osteoclasts [189]. Observational studies have confirmed the possible beneficial effects of L intake on total hip bone mineral density in men [42], supporting a positive role on bone health [190]. 
Interestingly, an RCT reported that L protected the skin against the damage induced by solar radiation [191]; Palombo et al. reported beneficial effects of both topical and oral $\mathrm{L}$ administration on skin elasticity and hydration [192] and similar results were observed by Morganti et al. [193]. However, it seems premature to claim that $\mathrm{L}$ exerts a protective effect on skin.

Finally, a few data also exist on a possible role of $\mathrm{L}$ in pregnancy, but, Lorenzoni et al. did not find any protective effect of $L$ on oxidative stress in women with gestational diabetes [194]. On the contrary, a case-control study by Cohen et al. suggested that higher plasma L concentrations were associated with low risk of preeclampsia [195]. Despite these findings, data concerning a protective role of carotenoids against as pregnancy diseases as outcomes have been considered inconclusive even by a recent review on the effects of carotenoids during pregnancy [196].

\section{Lutein Safety and Toxicity}

In a well-balanced diet, $\mathrm{L}$ intake is sufficient and there is no need for supplementation, but in the presence of inadequate absorption or chronic diseases this possibility needs careful consideration. Several studies have been carried out to establish reasonable upper limits of safety for daily supplementation and to describe possible side effects of chronic L supplementation. To date, no study reported toxicity, either in acute or during chronic L supplementation [197]. Studies performed both in animals [198,199] and in-vitro [199] clearly demonstrated that the use of $L$ is safe as no mutagenic or teratogenic effect was observed. Nevertheless, mice lacking Beta-Carotene Oxygenase 2 exhibited a pathologic carotenoids accumulation and a significant increase in oxidative stress and mitochondrial dysfunction [200] suggesting that an excessive carotenoid supplementation might lead to toxicity under certain conditions. Furthermore, epidemiological studies as well as intervention studies did not observe any toxic effect caused by L [201]. However, according to current evidence, the Joint Expert Committee on Food Additives established an upper safety limit for daily L intake of $2 \mathrm{mg} / \mathrm{kg}$ [202], while the European Food Safety Authority (EFSA) was more cautious and indicated a limit of $1 \mathrm{mg} / \mathrm{kg}$ [197]. This is consistent with the data obtained by Landrum et al. [203] and Dagnelie et al. [204] who demonstrated that the intake of $\mathrm{L}$ is safe up to 30 and $40 \mathrm{mg}$ per day respectively. The EFSA additionally set an upper limit for L-enriched milk for infants, establishing a maximum L supplementation of $250 \mu \mathrm{g} / \mathrm{L}$ [205]. Zheng et al. [206] demonstrated no interactions between L intake and cytochrome P450 enzyme activity; hence it is conceivable that $\mathrm{L}$ does not alter the metabolism of other exogenous or endogenous substances. Nevertheless, although $\mathrm{L}$ does not seem to be toxic, some side effects have been reported. Indeed, Olmedilla et al. [207] reported that subjects receiving L supplementation of $15 \mathrm{mg} / \mathrm{d}$ for 20 weeks developed skin yellowing [carotenodermia], an innocuous but unpleasant side effect. An observational study [208] hypothesized that L might be associated with an increased risk of lung cancer, especially among smokers. In particular, an association was observed between chronic intake of supplements also containing $L$ and an increased risk of lung cancer, mainly non-small cell lung cancer [208]. However, an accurate survey performed by the EFSA concluded that data were insufficient to consider that $\mathrm{L}$ supplementation is associated with such negative events [197]. Similarly, the AREDS2 intervention study did not observe any increased incidence of lung cancer with $\mathrm{L}$ supplementation suggesting that a health warning was unnecessary. A recent case report described the occurrence of crystalline maculopathy in an old woman on L supplementation and this potential side effect reversed after L intake discontinuation [209]. However, the absence of similar data throughout recent decades makes also this association unlikely. Therefore, based on available data, it is reasonable to conclude that chronic $L$ supplementation at the recommended dose of $10 \mathrm{mg} / \mathrm{d}$, as in the AREDS2 study, is safe and not toxic.

\section{Conclusions}

Lutein qualifies as a powerful antioxidant and many studies support its favorable effects on eye health. Also, L has beneficial effects on other tissues, especially the brain, where it was associated with improved cognitive performance. Thus, not only high L intake with a diet rich in fruit and vegetables, 
but also its supplementation might be encouraged, particularly in the elderly and in individuals at high risk of different clinical conditions. However, there are still conflicting data that need to be elucidated by randomized clinical trials with large cohorts of general population. Furthermore, most of the results available at present were obtained from clinical trials lasting less than 1 year. Therefore, this time span is probably not sufficient to show significant favorable effects; therefore, studies with a longer duration are needed to better elucidate the possible favorable role of $\mathrm{L}$ on human health.

Author Contributions: S.B. and D.C. designed, collected data and wrote the manuscript. F.D.P. and M.L.P. collected data and wrote part of the manuscript. A.S. collected and analyzed references concerning the cardiovascular aspects, revised and approved the final version. S.B. co-supervised, edited and corrected the draft manuscript, G.M. supervised, proofread, revised and approved the final version.

Funding: This research received no external funding.

Conflicts of Interest: The authors declare no conflict of interest.

\section{References}

1. Bjørklund, G.; Chirumbolo, S. Role of oxidative stress and antioxidants in daily nutrition and human health. Nutrition 2017, 33, 311-321. [CrossRef] [PubMed]

2. Chrysohoou, C.; Panagiotakos, D.B.; Pitsavos, C.; Das, U.N.; Stefanadis, C. Adherence to the Mediterranean diet attenuates inflammation and coagulation process in healthy adults: The ATTICA Study. J. Am. Coll. Cardiol. 2004, 44, 152-158. [CrossRef] [PubMed]

3. Di Daniele, N.; Noce, A.; Vidiri, M.F.; Moriconi, E.; Marrone, G.; Annicchiarico-Petruzzelli, M.; D’Urso, G.; Tesauro, M.; Rovella, V.; De Lorenzo, A. Impact of Mediterranean diet on metabolic syndrome, cancer and longevity. Oncotarget 2017, 8, 8947-8979. [CrossRef] [PubMed]

4. Perry, A.; Rasmussen, H.; Johnson, E.J. Xanthophyll [lutein, zeaxanthin] content in fruits, vegetables and corn and egg products. J. Food Compos. Anal. 2009, 22, 9-15. [CrossRef]

5. Fiedor, J.; Burda, K. Potential role of carotenoids as antioxidants in human health and disease. Nutrients 2014, 6, 466-488. [CrossRef] [PubMed]

6. Young, A.J.; Lowe, G.M. Antioxidant and prooxidant properties of carotenoids. Arch. Biochem. Biophys. 2001, 385, 20-27. [CrossRef] [PubMed]

7. Tapiero, H.; Townsend, D.M.; Tew, K.D. The role of carotenoids in the prevention of human pathologies. Biomed. Pharmacother. 2004, 58, 100-110. [CrossRef] [PubMed]

8. Lima, V.C.; Rosen, R.B.; Farah, M. Macular pigment in retinal health and disease. Int. J. Retina Vitreous 2016, 2, 19. [CrossRef] [PubMed]

9. Kim, S.R.; Nakanishi, K.; Itagaki, Y.; Sparrow, J.R. Photooxidation of A2-PE, a photoreceptor outer segment fluorophore, and protection by lutein and zeaxanthin. Exp. Eye Res. 2006, 82, 828-839. [CrossRef] [PubMed]

10. Seddon, J.M.; Ajani, U.A.; Sperduto, R.D.; Hiller, R.; Blair, N.; Burton, T.C.; Farber, M.D.; Gragoudas, E.S.; Haller, J.; Miller, D.T.; et al. Eye Disease Case-Control Study Group. Dietary carotenoids, vitamins A, C, and $\mathrm{E}$, and advanced age-related macular degeneration. JAMA 1994, 272, 1413-1420. [CrossRef] [PubMed]

11. Eroglu, A.; Harrison, E.H. Carotenoid metabolism in mammals, including man: Formation, occurrence, and function of apocarotenoids. J. Lipid Res. 2013, 54, 1719-1730. [CrossRef] [PubMed]

12. Richer, S.; Stiles, W.; Statkute, L.; Pulido, J.; Frankowski, J.; Rudy, D.; Pei, K.; Tsipursky, M.; Nyland, J. Double-masked, placebo-controlled, randomized trial of lutein and antioxidant supplementation in the intervention of atrophic age-related macular degeneration: The Veterans LAST study (Lutein Antioxidant Supplementation Trial). Optometry 2004, 75, 216-230. [CrossRef]

13. Parisi, V.; Tedeschi, M.; Gallinaro, G.; Varano, M.; Saviano, S.; Piermarocchi, S.; CARMIS Study Group. Carotenoids and antioxidants in age-related maculopathy Italian study: Multifocal electroretinogram modifications after 1 year. Ophthalmology 2008, 115, 324-333. [CrossRef] [PubMed]

14. Weigert, G.; Kaya, S.; Pemp, B.; Sacu, S.; Lasta, M.; Werkmeister, R.M.; Dragostinoff, N.; Simader, C.; Garhöfer, G.; Schmidt-Erfurth, U.; Schmetterer, L. Effects of lutein supplementation on macular pigment optical density and visual acuity in patients with age-related macular degeneration. Investig. Ophthalmol. Vis. Sci. 2011, 52, 8174-8178. [CrossRef] [PubMed] 
15. Beatty, S.; Chakravarthy, U.; Nolan, J.M.; Muldrew, K.A.; Woodside, J.V.; Denny, F.; Stevenson, M.R. Secondary outcomes in a clinical trial of carotenoids with coantioxidants versus placebo in early age-related macular degeneration. Ophthalmology 2013, 120, 600-606. [CrossRef] [PubMed]

16. Murray, I.J.; Makridaki, M.; van der Veen, R.L.; Carden, D.; Parry, N.R.; Berendschot, T.T. Lutein supplementation over a one-year period in early AMD might have a mild beneficial effect on visual acuity: The CLEAR study. Investig. Ophthalmol. Vis. Sci. 2013, 54, 1781-1788. [CrossRef] [PubMed]

17. Christen, W.G.; Liu, S.; Glynn, R.J.; Gaziano, J.M.; Buring, J.E. Dietary carotenoids, vitamins C and E, and risk of cataract in women: A prospective study. Arch. Ophthalmol. 2008, 126, 102-109. [CrossRef] [PubMed]

18. Vu, H.T.; Robman, L.; Hodge, A.; McCarty, C.A.; Taylor, H.R. Lutein and zeaxanthin and the risk of cataract: The Melbourne visual impairment project. Investig. Ophthalmol. Vis. Sci. 2006, 47, 3783-3786. [CrossRef] [PubMed]

19. Moeller, S.M.; Voland, R.; Tinker, L.; Blodi, B.A.; Klein, M.L.; Gehrs, K.M.; Johnson, E.J.; Snodderly, D.M.; Wallace, R.B.; Chappell, R.J.; et al. CAREDS Study Group. Associations between age-related nuclear cataract and lutein and zeaxanthin in the diet and serum in the Carotenoids in the Age-Related Eye Disease Study, an Ancillary Study of the Women's Health Initiative. Arch. Ophthalmol. 2008, 126, 354-364. [CrossRef] [PubMed]

20. Brown, L.; Rimm, E.B.; Seddon, J.M.; Giovannucci, E.L.; Chasan-Taber, L.; Spiegelman, D.; Willett, W.C.; Hankinson, S.E. A prospective study of carotenoid intake and risk of cataract extraction in US men. Am. J. Clin. Nutr. 1999, 70, 517-524. [CrossRef] [PubMed]

21. Chasan-Taber, L.; Willett, W.C.; Seddon, J.M.; Stampfer, M.J.; Rosner, B.; Colditz, G.A.; Speizer, F.E.; Hankinson, S.E. A prospective study of carotenoid and vitamin A intakes and risk of cataract extraction in US women. Am. J. Clin. Nutr. 1999, 70, 509-516. [CrossRef] [PubMed]

22. Rosenthal, J.M.; Kim, J.; de Monasterio, F.; Thompson, D.J.; Bone, R.A.; Landrum, J.T.; de Moura, F.F.; Khachik, F.; Chen, H.; Schleicher, R.L.; Ferris, F.L., III; Chew, E.Y. Dose-ranging study of lutein supplementation in persons aged 60 years or older. Invest. Ophthalmol. Vis. Sci. 2006, 47, 5227-5233. [CrossRef] [PubMed]

23. Ma, L.; Lin, X.M.; Zou, Z.Y.; Xu, X.R.; Li, Y.; Xu, R. A 12-week lutein supplementation improves visual function in Chinese people with long-term computer display light exposure. Br. J. Nutr. 2009, 102, 186-190. [CrossRef] [PubMed]

24. Sasamoto, Y.; Gomi, F.; Sawa, M.; Tsujikawa, M.; Nishida, K. Effect of 1-year lutein supplementation on macular pigment optical density and visual function. Graefes Arch. Clin. Exp. Ophthalmol. 2011, 249, 1847-1854. [CrossRef] [PubMed]

25. Obana, A.; Tanito, M.; Gohto, Y.; Okazaki, S.; Gellermann, W.; Bernstein, P.S. Changes in macular pigment optical density and serum lutein concentration in Japanese subjects taking two different lutein supplements. PLoS ONE 2015, 10, e0139257. [CrossRef] [PubMed]

26. Berrow, E.J.; Bartlett, H.E.; Eperjesi, F.; Gibson, J.M. The effects of a lutein-based supplement on objective and subjective measures of retinal and visual function in eyes with age-related maculopathy-A randomised controlled trial. Br. J. Nutr. 2013, 109, 2008-2014. [CrossRef] [PubMed]

27. Age-Related Eye Disease Study 2 Research Group. Lutein + zeaxanthin and omega-3 fatty acids for age-related macular degeneration: The Age-Related Eye Disease Study 2 [AREDS2] randomized clinical trial. JAMA 2013, 309, 2005-2015. [CrossRef] [PubMed]

28. Korobelnik, J.F.; Rougier, M.B.; Delyfer, M.N.; Bron, A.; Merle, B.M.J.; Savel, H.; Chêne, G.; Delcourt, C.; Creuzot-Garcher, C. Effect of Dietary Supplementation with Lutein, Zeaxanthin, and $\omega-3$ on Macular Pigment: A Randomized Clinical Trial. JAMA Ophthalmol. 2017, 135, 1259-1266. [CrossRef] [PubMed]

29. Chong, E.W.; Wong, T.Y.; Kreis, A.J.; Simpson, J.A.; Guymer, R.H. Dietary antioxidants and primary prevention of age related macular degeneration: Systematic review and meta-analysis. BMJ 2007, 335, 755. [CrossRef] [PubMed]

30. Cho, E.; Hankinson, S.E.; Rosner, B.; Willett, W.C.; Colditz, G.A. Prospective study of lutein/zeaxanthin intake and risk of age-related macular degeneration. Am. J. Clin. Nutr. 2008, 87, 1837-1843. [CrossRef] [PubMed]

31. Trumbo, P.R.; Ellwood, K.C. Lutein and zeaxanthin intakes and risk of age-related macular degeneration and cataracts: An evaluation using the Food and Drug Administration's evidence-based review system for health claims. Am. J. Clin. Nutr. 2006, 84, 971-974. [CrossRef] [PubMed] 
32. Wang, X.; Jiang, C.; Zhang, Y.; Gong, Y.; Chen, X.; Zhang, M. Role of lutein supplementation in the management of age-related macular degeneration: Meta-analysis of randomized controlled trials. Ophthalmic Res. 2014, 52, 198-205. [CrossRef] [PubMed]

33. Liu, R.; Wang, T.; Zhang, B.; Qin, L.; Wu, C.; Li, Q.; Ma, L. Lutein and zeaxanthin supplementation and association with visual function in age-related macular degeneration. Investig. Ophthalmol. Vis. Sci. 2014, 56, 252-258. [CrossRef] [PubMed]

34. Stringham, J.M.; Stringham, N.T. Serum and retinal responses to three different doses of macular carotenoids over 12 weeks of supplementation. Exp. Eye Res. 2016, 151, 1-8. [CrossRef] [PubMed]

35. Dawczynski, J.; Jentsch, S.; Schweitzer, D.; Hammer, M.; Lang, G.E.; Strobel, J. Long term effects of lutein, zeaxanthin and omega-3-LCPUFAs supplementation on optical density of macular pigment in AMD patients: The LUTEGA study. Graefes Arch. Clin. Exp. Ophthalmol. 2013, 251, 2711-2723. [CrossRef] [PubMed]

36. Huang, Y.M.; Dou, H.L.; Huang, F.F.; Xu, X.R.; Zou, Z.Y.; Lin, X.M. Effect of supplemental lutein and zeaxanthin on serum, macular pigmentation, and visual performance in patients with early age-related macular degeneration. Biomed. Res. Int. 2015, 2015, 564738. [CrossRef] [PubMed]

37. Ma, L.; Yan, S.F.; Huang, Y.M.; Lu, X.R.; Qian, F.; Pang, H.L.; Xu, X.R.; Zou, Z.Y.; Dong, P.C.; Xiao, X.; et al. Effect of lutein and zeaxanthin on macular pigment and visual function in patients with early age-related macular degeneration. Ophthalmology 2012, 119, 2290-2297. [CrossRef] [PubMed]

38. Bone, R.A.; Landrum, J.T. Dose-dependent response of serum lutein and macular pigment optical density to supplementation with lutein esters. Arch. Biochem. Biophys. 2010, 504, 50-55. [CrossRef] [PubMed]

39. Chung, R.W.S.; Leanderson, P.; Lundberg, A.K.; Jonasson, L. Lutein exerts anti-inflammatory effects in patients with coronary artery disease. Atherosclerosis 2017, 262, 87-93. [CrossRef] [PubMed]

40. Johnson, E.J.; Vishwanathan, R.; Johnson, M.A.; Hausman, D.B.; Davey, A.; Scott, T.M.; Green, R.C.; Miller, L.S.; Gearing, M.; Woodard, J.; et al. Relationship between serum and brain carotenoids, $\alpha$-tocopherol, and retinol concentrations and cognitive performance in the oldest old from the Georgia Centenarian Study. J. Aging Res. 2013, 2013, 951786. [CrossRef] [PubMed]

41. Slattery, M.L.; Benson, J.; Curtin, K.; Ma, K.N.; Schaeffer, D.; Potter, J.D. Carotenoids and colon cancer. Am. J. Clin. Nutr. 2000, 71, 575-582. [CrossRef] [PubMed]

42. Regu, G.M.; Kim, H.; Kim, Y.J.; Paek, J.E.; Lee, G.; Chang, N.; Kwon, O. Association between dietary carotenoid intake and bone mineral density in Korean adults aged 30-75 years using data from the fourth and fifth Korean national health and nutrition examination surveys [2008-2011]. Nutrients 2017, 9, 1025. [CrossRef] [PubMed]

43. Cao, Y.; Wang, C.; Liu, J.; Liu, Z.M.; Ling, W.H.; Chen, Y.M. Greater serum carotenoid levels associated with lower prevalence of nonalcoholic fatty liver disease in Chinese adults. Sci. Rep. 2015, 5, 12951. [CrossRef] [PubMed]

44. Schünemann, H.J.; McCann, S.; Grant, B.J.; Trevisan, M.; Muti, P.; Freudenheim, J.L. Lung function in relation to intake of carotenoids and other antioxidant vitamins in a population-based study. Am. J. Epidemiol. 2002, 155, 463-471. [CrossRef] [PubMed]

45. Bone, R.A.; Landrum, J.T.; Tarsis, S.L. Preliminary identification of the human macular pigment. Vis. Res. 1985, 25, 1531-1535. [CrossRef]

46. Bone, R.A.; Landrum, J.T.; Hime, G.W.; Cains, A.; Zamor, J. Stereochemistry of the human macular carotenoids. Investig. Ophthalmol. Vis. Sci. 1993, 34, 2033-2040.

47. Snodderly, D.M.; Brown, P.K.; Delori, F.C.; Auran, J.D. The macular pigment. I. Absorbance spectra, localization, and discrimination from other yellow pigments in primate retinas. Investig. Ophthalmol. Vis. Sci. 1984, 25, 660-673.

48. Gass, J.D. Müller cell cone, an overlooked part of the anatomy of the fovea centralis: Hypotheses concerning its role in the pathogenesis of macular hole and foveomacular retinoschisis. Arch. Ophthalmol. 1999, 117, 821-823. [CrossRef] [PubMed]

49. Bone, R.A.; Landrum, J.T.; Friedes, L.M.; Gomez, C.M.; Kilburn, M.D.; Menendez, E.; Vidal, I.; Wang, W. Distribution of lutein and zeaxanthin stereoisomers in the human retina. Exp. Eye Res. 1997, 64, 211-218. [CrossRef] [PubMed]

50. Bone, R.A.; Landrum, J.T.; Fernandez, L.; Tarsis, S.L. Analysis of the macular pigment by HPLC: Retinal distribution and age study. Investig. Ophthalmol. Vis. Sci. 1988, 29, 843-849. 
51. Snodderly, D.M.; Auran, J.D.; Delori, F.C. The macular pigment. II. Spatial distribution in primate retinas. Investig. Ophthalmol. Vis. Sci. 1984, 25, 674-685.

52. Bernstein, P.S.; Khachik, F.; Carvalho, L.S.; Muir, G.J.; Zhao, D.Y.; Katz, N.B. Identification and quantitation of carotenoids and their metabolites in the tissues of the human eye. Exp. Eye Res. 2001, 72, 215-223. [CrossRef] [PubMed]

53. Sato, Y.; Kondo, Y.; Sumi, M.; Takekuma, Y.; Sugawara, M. Intracellular uptake mechanism of lutein in retinal pigment epithelial cells. J. Pharm. Pharm. Sci. 2013, 16, 494-501. [CrossRef] [PubMed]

54. Vishwanathan, R.; Kuchan, M.J.; Sen, S.; Johnson, E.J. Lutein and preterm infants with decreased concentrations of brain carotenoids. J. Pediatr. Gastroenterol. Nutr. 2014, 59, 659-665. [CrossRef] [PubMed]

55. Craft, N.E.; Haitema, T.B.; Garnett, K.M.; Fitch, K.A.; Dorey, C.K. Carotenoid, tocopherol, and retinol concentrations in elderly human brain. J. Nutr. Health Aging 2004, 8, 156-162. [PubMed]

56. Parker, R.S. Absorption, metabolism, and transport of carotenoids. FASEB J. 1996, 10, 542-551. [CrossRef] [PubMed]

57. Clevidence, B.A.; Bieri, J.G. Association of carotenoids with human plasma lipoproteins. Methods Enzymol. 1993, 214, 33-46. [CrossRef] [PubMed]

58. Ribaya-Mercado, J.D.; Ordovas, J.M.; Russell, R.M. Effect of beta-carotene supplementation on the concentrations and distribution of carotenoids, vitamin E, vitamin A, and cholesterol in plasma lipoprotein and non-lipoprotein fractions in healthy older women. J. Am. Coll. Nutr. 1995, 14, 614-620. [CrossRef] [PubMed]

59. Bernstein, P.S.; Lia, B.; Vachalia, P.P.; Gorusupudia, A.; Shyama, R.; Henriksen, B.S.; Nolan, J.M. Lutein, Zeaxanthin, and meso-Zeaxanthin: The basic and clinical science underlying carotenoid-based nutritional interventions against ocular disease. Prog. Retin. Eye Res. 2016, 50, 34-66. [CrossRef] [PubMed]

60. Castenmiller, J.J.; West, C.E.; Linssen, J.P.; van het Hof, K.H.; Voragen, A.G. The food matrix of spinach is a limiting factor in determining the bioavailability of beta-carotene and to a lesser extent of lutein in humans. J. Nutr. 1999, 129, 349-355. [CrossRef] [PubMed]

61. Unlu, N.Z.; Bohn, T.; Clinton, S.K.; Schwartz, S.J. Carotenoid absorption from salad and salsa by humans is enhanced by the addition of avocado or avocado oil. J. Nutr. 2005, 135, 431-436. [CrossRef] [PubMed]

62. Rock, C.L.; Swendseid, M.E. Plasma beta-carotene response in humans after meals supplemented with dietary pectin. Am. J. Clin. Nutr. 1992, 55, 96-99. [CrossRef] [PubMed]

63. Riedl, J.; Linseisen, J.; Hoffmann, J.; Wolfram, G. Some dietary fibers reduce the absorption of carotenoids in women. J. Nutr. 1999, 129, 2170-2176. [CrossRef] [PubMed]

64. Kostic, D.; White, W.S.; Olson, J.A. Intestinal absorption, serum clearance, and interactions between lutein and beta-carotene when administered to human adults in separate or combined oral doses. Am. J. Clin. Nutr. 1995, 62, 604-610. [CrossRef] [PubMed]

65. Williams, A.W.; Boileau, T.W.; Erdman, J.W., Jr. Factors influencing the uptake and absorption of carotenoids. Proc. Soc. Exp. Biol. Med. 1998, 218, 106-108. [CrossRef] [PubMed]

66. Marriage, B.J.; Williams, J.A.; Choe, Y.S.; Maki, K.C.; Vurma, M.; DeMichele, S.J. Mono- and diglycerides improve lutein absorption in healthy adults: A randomised, double-blind, cross-over, single-dose study. Br. J. Nutr. 2017, 118, 813-821. [CrossRef] [PubMed]

67. Sundl, I.; Pail, E.; Mellitzer, K.; Toplak, H.; Winklhofer-Roob, B.M. Effects of orlistat therapy on plasma concentrations of oxygenated and hydrocarbon carotenoids. Lipids 2006, 41, 113-118. [CrossRef] [PubMed]

68. Tang, G.; Serfaty-Lacrosniere, C.; Camilo, M.E.; Russell, R.M. Gastric acidity influences the blood response to a beta-carotene dose in humans. Am. J. Clin. Nutr. 1996, 64, 622-626. [CrossRef] [PubMed]

69. Winklhofer-Roob, B.M.; Puhl, H.; Khoschsorur, G.; van't Hof, M.A.; Esterbauer, H.; Shmerling, D.H. Enhanced resistance to oxidation of low density lipoproteins and decreased lipid peroxide formation during beta-carotene supplementation in cystic fibrosis. Free Radic. Biol. Med. 1995, 18, 849-859. [CrossRef]

70. Alberg, A. The influence of cigarette smoking on circulating concentrations of antioxidant micronutrients. Toxicology 2002, 180, 121-137. [CrossRef]

71. Albanes, D.; Virtamo, J.; Taylor, P.R.; Rautalahti, M.; Pietinen, P.; Heinonen, O.P. Effects of supplemental beta-carotene, cigarette smoking, and alcohol consumption on serum carotenoids in the Alpha-Tocopherol, Beta-Carotene Cancer Prevention Study. Am. J. Clin. Nutr. 1997, 66, 366-372. [CrossRef] [PubMed]

72. Kijlstra, A.; Tian, Y.; Kelly, E.R.; Berendschot, T.T. Lutein: More than just a filter for blue light. Prog. Retin. Eye Res. 2012, 31, 303-315. [CrossRef] [PubMed] 
73. Junghans, A.; Sies, H.; Stahl, W. Macular pigments lutein and zeaxanthin as blue light filters studied in liposomes. Arch. Biochem. Biophys. 2001, 391, 160-164. [CrossRef] [PubMed]

74. Subczynski, W.K.; Wisniewska, A.; Widomska, J. Location of macular xanthophylls in the most vulnerable regions of photoreceptor outer-segment membranes. Arch. Biochem. Biophys. 2010, 504, 61-66. [CrossRef] [PubMed]

75. Liu, T.; Liu, W.H.; Zhao, J.S.; Meng, F.Z.; Wang, H. Lutein protects against $\beta$-amyloid peptide-induced oxidative stress in cerebrovascular endothelial cells through modulation of Nrf-2 and NF-kb. Cell. Biol. Toxicol. 2017, 33, 57-67. [CrossRef] [PubMed]

76. Chang, J.; Zhang, Y.; Li, Y.; Lu, K.; Shen, Y.; Guo, Y.; Qi, Q.; Wang, M.; Zhang, S. NrF2 / ARE and NF-kB pathway regulation may be the mechanism for lutein inhibition of human breast cancer cell. Future Oncol. 2018, 14, 719-726. [CrossRef] [PubMed]

77. Muriach, M.; Bosch-Morell, F.; Arnal, E.; Alexander, G.; Blomhoff, R.; Romero, F.J. Lutein prevents the effect of high glucose levels on immune system cells in vivo and in vitro. J. Physiol. Biochem. 2008, 64, 149-157. [CrossRef] [PubMed]

78. Li, S.; Ding, Y.; Niu, Q.; Xu, S.; Pang, L.; Ma, R.; Jing, M.; Feng, G.; Tang, J.X.; Zhang, Q.; et al. Lutein has a protective effect on hepatotoxicity induced by arsenic via Nrf2 signaling. BioMed Res. Int. 2015, 2015, 315205. [CrossRef] [PubMed]

79. Rafi, M.M.; Shafaie, Y. Dietary lutein modulates inducible nitric oxide synthase (iNOS) gene and protein expression in mouse macrophage cells (RAW 264.7). Mol. Nutr. Food Res. 2007, 51, 333-340. [CrossRef] [PubMed]

80. Tian, Y.; Kijlstra, A.; van der Veen, R.L.; Makridaki, M.; Murray, I.J.; Berendschot, T.T. Lutein supplementation leads to decreased soluble complement membrane attack complex sC5b-9 plasma levels. Acta Ophthalmol. 2015, 93, 141-145. [CrossRef] [PubMed]

81. Chung, H.Y.; Rasmussen, H.M.; Johnson, E.J. Lutein bioavailability is higher from lutein-enriched eggs than from supplements and spinach in men. J. Nutr. 2004, 134, 1887-1893. [CrossRef] [PubMed]

82. Johnson, E.J.; Maras, J.E.; Rasmussen, H.M.; Tucker, K.L. Intake of lutein and zeaxanthin differ with age, sex, and ethnicity. J. Am. Diet. Assoc. 2010, 110, 1357-1362. [CrossRef] [PubMed]

83. United States Department of Agriculture, Agricultural Research Service. What We Eat in America, NHANES 2011-2012; USDA ARS: Washington, DC, USA, 2014. Available online: http:/ / www.ars.usda.gov/Services / docs.htm?docid=13793 (accessed on 1 July 2018).

84. Olmedilla-Alonso, B.; Beltrán-de-Miguel, B.; Estévez-Santiago, R.; Cuadrado-Vives, C. Markers of lutein and zeaxanthin status in two age groups of men and women: Dietary intake, serum concentrations, lipid profile and macular pigment optical density. Nutr. J. 2014, 13, 52. [CrossRef] [PubMed]

85. O’Neill, M.E.; Carroll, Y.; Corridan, B.; Olmedilla, B.; Granado, F.; Blanco, I.; Van den Berg, H.; Hininger, I.; Rousell, A.M.; Chopra, M.; et al. A European carotenoid database to assess carotenoid intakes and its use in a five-country comparative study. Br. J. Nutr. 2001, 85, 499-507. [CrossRef] [PubMed]

86. Lee, H.S.; Cho, Y.H.; Park, J.; Shin, H.R.; Sung, M.K. Dietary intake of phytonutrients in relation to fruit and vegetable consumption in Korea. J. Acad. Nutr. Diet. 2013, 113, 1194-1199. [CrossRef] [PubMed]

87. Le Marchand, L.; Hankin, J.H.; Bach, F.; Kolonel, L.N.; Wilkens, L.R.; Stacewicz-Sapuntzakis, M.; Bowen, P.E.; Beecher, G.R.; Laudon, F.; Baque, P.; et al. An ecological study of diet and lung cancer in the South Pacific. Int. J. Cancer 1995, 63, 18-23. [CrossRef] [PubMed]

88. Available online: https://ndb.nal.usda.gov/ndb/nutrients/report/nutrientsfrm? $\max =25 \&$ offset $=0 \&$ totCount $=0$ \&nutrient $1=338 \&$ nutrient $2=\&$ nutrient $3=\&$ subset $=0 \&$ sort $=c \&$ measureby $=g \quad$ (accessed on 1 July 2018).

89. Wong, W.L.; Su, X.; Li, X.; Cheung, C.M.; Klein, R.; Cheng, C.Y.; Wong, T.Y. Global prevalence of age-related macular degeneration and disease burden projection for 2020 and 2040: A systematic review and meta-analysis. Lancet Glob. Health 2014, 2, e106-e116. [CrossRef]

90. Lim, L.S.; Mitchell, P.; Seddon, J.M.; Holz, F.G.; Wong, T.Y. Age-related macular degeneration. Lancet 2012, 379, 1728-1738. [CrossRef]

91. Abdel-Aal, E.-S.M.; Akhtar, H.; Zaheer, K.; Ali, R. Dietary sources of lutein and zeaxanthin carotenoids and their role in eye health. Nutrients 2013, 5, 1169-1185. [CrossRef] [PubMed] 
92. Akuffo, K.O.; Nolan, J.M.; Howard, A.N.; Moran, R.; Stack, J.; Klein, R.; Klein, B.E.; Meuer, S.M.; Sabour-Pickett, S.; Thurnham, D.I.; et al. Sustained supplementation and monitored response with differing carotenoid formulations in early age-related macular degeneration. Eye 2015, 29, 902-912. [CrossRef] [PubMed]

93. Yao, Y.; Qiu, Q.H.; Wu, X.W.; Cai, Z.Y.; Xu, S.; Liang, X.Q. Lutein supplementation improves visual performance in Chinese drivers: 1-year randomized, double-blind, placebo-controlled study. Nutrition 2013, 29, 958-964. [CrossRef] [PubMed]

94. Huang, Y.M.; Dou, H.L.; Huang, F.F.; Xu, X.R.; Zou, Z.Y.; Lu, X.R.; Lin, X.M. Changes following supplementation with lutein and zeaxanthin in retinal function in eyes with early age-related macular degeneration: A randomised, double-blind, placebo-controlled trial. Br. J. Ophthalmol. 2015, 99, 371-375. [CrossRef] [PubMed]

95. Richer, S.P.; Stiles, W.; Graham-Hoffman, K.; Levin, M.; Ruskin, D.; Wrobel, J.; Park, D.W.; Thomas, C. Randomized, double-blind, placebo-controlled study of zeaxanthin and visual function in patients with atrophic age-related macular degeneration: The Zeaxanthin and Visual Function Study (ZVF) FDA IND \#78, 973. Optometry 2011, 82, 667-680. [CrossRef] [PubMed]

96. Fujimura, S.; Ueda, K.; Nomura, Y.; Yanagi, Y. Preliminary analysis of the relationship between serum lutein and zeaxanthin levels and macular pigment optical density. Clin. Ophthalmol. 2016, 10, 2149-2155. [CrossRef] [PubMed]

97. Hammond, B.R.; Fletcher, L.M.; Roos, F.; Wittwer, J.; Schalch, W. A double-blind, placebo-controlled study on the effects of lutein and zeaxanthin on photostress recovery, glare disability, and chromatic contrast. Investig. Ophthalmol. Vis. Sci. 2014, 55, 8583-8589. [CrossRef] [PubMed]

98. Nolan, J.M.; Loughman, J.; Akkali, M.C.; Stack, J.; Scanlon, G.; Davison, P.; Beatty, S. The impact of macular pigment augmentation on visual performance in normal subjects: COMPASS. Vis. Res. 2011, 51, 459-469. [CrossRef] [PubMed]

99. Wolf-Schnurrbusch, U.E.; Zinkernagel, M.S.; Munk, M.R.; Ebneter, A.; Wolf, S. Oral lutein supplementation enhances macular pigment density and contrast sensitivity but not in combination with polyunsaturated fatty acids. Investig. Ophthalmol. Vis. Sci. 2015, 56, 8069-8074. [CrossRef] [PubMed]

100. Sabour-Pickett, S.; Beatty, S.; Connolly, E.; Loughman, J.; Stack, J.; Howard, A.; Klein, R.; Klein, B.E.; Meuer, S.M.; Myers, C.E.; et al. Supplementation with three different macular carotenoid formulations in patients with early age-related macular degeneration. Retina 2014, 34, 1757-1766. [CrossRef] [PubMed]

101. Cangemi, F.E. TOZAL Study: An open case control study of an oral antioxidant and omega-3 supplement for dry AMD. BMC Ophthalmol. 2007, 7, 3. [CrossRef] [PubMed]

102. Piermarocchi, S.; Saviano, S.; Parisi, V.; Tedeschi, M.; Panozzo, G.; Scarpa, G.; Boschi, G.; Lo Giudice, G.; Carmis Study Group. Carotenoids in Age-related Maculopathy Italian Study [CARMIS]: Two-year results of a randomized study. Eur. J. Ophthalmol. 2012, 22, 216-225. [CrossRef] [PubMed]

103. Eye Disease Case-Control Study Group. Antioxidant status and neovascular age-related macular degeneration. Arch. Ophthalmol. 1993, 111, 104-109. [CrossRef]

104. Age-Related Eye Disease Study Research Group. A randomized, placebo-controlled, clinical trial of high dose supplementation with vitamins $\mathrm{C}$ and $\mathrm{E}$, beta carotene, and zinc for age-related macular degeneration and vision loss: AREDS report no. 8. Arch. Ophthalmol. 2001, 119, 1417-1436. [CrossRef]

105. Age-Related Eye Disease Study 2 (AREDS2) Research Group; Chew, E.Y.; Clemons, T.E.; Sangiovanni, J.P.; Danis, R.P.; Ferris, F.L., III; Elman, M.J.; Antoszyk, A.N.; Ruby, A.J.; Orth, D.; et al. Secondary analyses of the effects of lutein/zeaxanthin on age-related macular degeneration progression: AREDS2 report No. 3. JAMA Ophthalmol. 2014, 132, 142-149. [CrossRef] [PubMed]

106. Albanes, D.; Heinonen, O.P.; Huttunen, J.K.; Taylor, P.R.; Virtamo, J.; Edwards, B.K.; Haapakoski, J.; Rautalahti, M.; Hartman, A.M.; Palmgren, J. Effects of alpha-tocopherol and beta-carotene supplements on cancer incidence in the Alpha-Tocopherol Beta-Carotene Cancer Prevention Study. Am. J. Clin. Nutr. 1995, 62, 1427S-1430S. [CrossRef] [PubMed]

107. Omenn, G.S.; Goodman, G.E.; Thornquist, M.D.; Balmes, J.; Cullen, M.R.; Glass, A.; Keogh, J.P.; Meyskens, F.L., Jr.; Valanis, B.; Williams, J.H., Jr.; et al. Risk factors for lung cancer and for intervention effects in CARET, the Beta-Carotene and Retinol Efficacy Trial. J. Natl. Cancer Inst. 1996, 88, 1550-1559. [CrossRef] [PubMed] 
108. Ho, L.; van Leeuwen, R.; Witteman, J.C.; van Duijn, C.M.; Uitterlinden, A.G.; Hofman, A.; de Jong, P.T.; Vingerling, J.R.; Klaver, C.C. Reducing the genetic risk of age-related macular degeneration with dietary antioxidants, zinc, and $\omega-3$ fatty acids: The Rotterdam study. Arch. Ophthalmol. 2011, 129, 758-766. [CrossRef] [PubMed]

109. Chitchumroonchokchai, C.; Bomser, J.A.; Glamm, J.E.; Failla, M.L. Xanthophylls and alpha-tocopherol decrease UVB-induced lipid peroxidation and stress signaling in human lens epithelial cells. J. Nutr. 2004, 134, 3225-3232. [CrossRef] [PubMed]

110. Liu, Y.C.; Wilkins, M.; Kim, T.; Malyugin, B.; Mehta, J.S. Cataracts. Lancet 2017, 390, 600-612. [CrossRef]

111. $\mathrm{Hu}, \mathrm{Y}$; $\mathrm{Xu}, \mathrm{Z}$.J. Effects of lutein on the growth and migration of bovine lens epithelial cells in vitro. Huazhong Univ. Sci. Technol. Med. Sci. 2008, 28, 360-363. [CrossRef] [PubMed]

112. Jacques, P.F.; Taylor, A.; Moeller, S.; Hankinson, S.E.; Rogers, G.; Tung, W.; Ludovico, J.; Willett, W.C.; Chylack, L.T., Jr. Long-term nutrient intake and 5-year change in nuclear lens opacities. Arch. Ophthalmol. 2005, 123, 517-526. [CrossRef] [PubMed]

113. Yeum, K.J.; Shang, F.M.; Schalch, W.M.; Russell, R.M.; Taylor, A. Fat-soluble nutrient concentrations in different layers of human cataractous lens. Curr. Eye Res. 1999, 19, 502-505. [CrossRef] [PubMed]

114. Karppi, J.; Laukkanen, J.A.; Kurl, S. Plasma lutein and zeaxanthin and the risk of age-related nuclear cataract among the elderly Finnish population. Br. J. Nutr. 2012, 108, 148-154. [CrossRef] [PubMed]

115. Gale, C.R.; Hall, N.F.; Phillips, D.I.; Martyn, C.N. Plasma antioxidant vitamins and carotenoids and age-related cataract. Ophthalmology 2001, 108, 1992-1998. [CrossRef]

116. Olmedilla, B.; Granado, F.; Blanco, I.; Vaquero, M. Lutein, but not alpha-tocopherol, supplementation improves visual function in patients with age-related cataracts: A 2-y double-blind, placebo-controlled pilot study. Nutrition 2003, 19, 21-24. [CrossRef]

117. Olmedilla, B.; Granado, F.; Blanco, I.; Vaquero, M.; Cajiga, L. Lutein in patients with cataracts and age-related macular degeneration: A long-term supplementation study. J. Sci. Food Agric. 2001, 81, 904-909. [CrossRef]

118. Lyle, B.J.; Mares-Perlman, J.A.; Klein, B.E.; Klein, R.; Palta, M.; Bowen, P.E.; Greger, J.L. Serum carotenoids and tocopherols and incidence of age-related nuclear cataract. Am. J. Clin. Nutr. 1999, 69, 272-277. [CrossRef] [PubMed]

119. Lyle, B.J.; Mares-Perlman, J.A.; Klein, B.E.; Klein, R.; Greger, J.L. Antioxidant intake and risk of incident age-related nuclear cataracts in the Beaver Dam Eye Study. Am. J. Epidemiol. 1999, 149, 801-809. [CrossRef] [PubMed]

120. Age-Related Eye Disease Study 2 (AREDS2) Research Group; Chew, E.Y.; San Giovanni, J.P.; Ferris, F.L.; Wong, W.T.; Agron, E.; Clemons, T.E.; Sperduto, R.; Danis, R.; Chandra, S.R.; et al. Lutein/zeaxanthin for the treatment of age-related cataract: AREDS2 randomized trial report no. 4. JAMA Ophthalmol. 2013, 131, 843-850. [CrossRef] [PubMed]

121. Liu, X.H.; Yu, R.B.; Liu, R.; Hao, Z.X.; Han, C.C.; Zhu, Z.H.; Ma, L. Association between lutein and zeaxanthin status and the risk of cataract: A meta-analysis. Nutrients 2014, 6, 452-465. [CrossRef] [PubMed]

122. Ma, L.; Hao, Z.X.; Liu, R.R.; Yu, R.B.; Shi, Q.; Pan, J.P. A dose-response meta-analysis of dietary lutein and zeaxanthin intake in relation to risk of age-related cataract. Graefes Arch. Clin. Exp. Ophthalmol. 2014, 252, 63-70. [CrossRef] [PubMed]

123. Mares-Perlman, J.A.; Millen, A.E.; Ficek, T.L.; Hankinson, S.E. The body of evidence to support a protective role for lutein and zeaxanthin in delaying chronic disease. Overview. J. Nutr. 2002, 132, 518S-524S. [CrossRef] [PubMed]

124. Weikel, K.A.; Garber, C.; Baburins, A.; Taylor, A. Nutritional modulation of cataract. Nutr. Rev. 2014, 72, 30-47. [CrossRef] [PubMed]

125. Zhang, P.C.; Wu, C.R.; Wang, Z.L.; Wang, L.Y.; Han, Y.; Sun, S.L.; Li, Q.S.; Ma, L. Effect of lutein supplementation on visual function in nonproliferative diabetic retinopathy. Asia Pac. J. Clin. Nutr. 2017, 26, 406-411. [CrossRef] [PubMed]

126. Sahli, M.W.; Mares, J.A.; Meyers, K.J.; Klein, R.; Brady, W.E.; Klein, B.E.; Ochs-Balcom, H.M.; Donahue, R.P.; Millen, A.E. Dietary intake of lutein and diabetic retinopathy in the Atherosclerosis Risk in Communities Study (ARIC). Ophthalmic Epidemiol. 2016, 23, 99-108. [CrossRef] [PubMed]

127. Bahrami, H.; Melia, M.; Dagnelie, G. Lutein supplementation in retinitis pigmentosa: PC-based vision assessment in a randomized double-masked placebo-controlled clinical trial [NCT00029289]. BMC Ophthalmol. 2006, 6, 23. [CrossRef] [PubMed] 
128. Aleman, T.S.; Duncan, J.L.; Bieber, M.L.; de Castro, E.; Marks, D.A.; Gardner, L.M.; Steinberg, J.D.; Cideciyan, A.V.; Maguire, M.G.; Jacobson, S.G. Macular pigment and lutein supplementation in retinitis pigmentosa and Usher syndrome. Investig. Ophthalmol. Vis. Sci. 2001, 42, 1873-1881.

129. Adackapara, C.A.; Sunness, J.S.; Dibernardo, C.W.; Melia, B.M.; Dagnelie, G. Prevalence of cystoid macular edema and stability in oct retinal thickness in eyes with retinitis pigmentosa during a 48-week lutein trial. Retina 2008, 28, 103-110. [CrossRef] [PubMed]

130. Chen, J.; Smith, L.E. Retinopathy of prematurity. Angiogenesis 2007, 10, 133-140. [CrossRef] [PubMed]

131. Fu, Z.; Meng, S.S.; Burnim, S.B.; Smith, L.E.; Lo, A.C. Lutein facilitates physiological revascularization in a mouse model of retinopathy of prematurity. Clin. Exp. Ophthalmol. 2017, 45, 529-538. [CrossRef] [PubMed]

132. Dani, C.; Lori, I.; Favelli, F.; Frosini, S.; Messner, H.; Wanker, P.; De Marini, S.; Oretti, C.; Boldrini, A.; Ciantelli, M.; et al. Lutein and zeaxanthin supplementation in preterm infants to prevent retinopathy of prematurity: A randomized controlled study. J. Maternal Fetal Neonatal Med. 2012, 25, 523-527. [CrossRef] [PubMed]

133. Feeney, J.; O’Leary, N.; Moran, R.; O’Halloran, A.M.; Nolan, J.M.; Beatty, S.; Young, I.S.; Kenny, R.A. Plasma lutein and zeaxanthin are associated with better cognitive function across multiple domains in a large population-based sample of older adults: Findings from the Irish Longitudinal Study on Aging. J. Gerontol. A Biol. Sci. Med. Sci. 2017, 72, 1431-1436. [CrossRef] [PubMed]

134. Zamroziewicz, M.K.; Paul, E.J.; Zwilling, C.E.; Johnson, E.J.; Kuchan, M.J.; Cohen, N.J.; Barbey, A.K. Parahippocampal cortex mediates the relationship between lutein and crystallized intelligence in healthy, older adults. Front. Aging Neurosci. 2016, 8, 297. [CrossRef] [PubMed]

135. Picone, S.; Ritieni, A.; Fabiano, A.; Graziani, G.; Paolillo, P.; Livolti, G.; Galvano, F.; Gazzolo, D. Lutein levels in arterial cord blood correlate with neuroprotein activin A in healthy preterm and term newborns: A trophic role for lutein? Clin. Biochem. 2018, 52, 80-84. [CrossRef] [PubMed]

136. Lai, M.; Sirimanne, E.; Williams, C.E.; Gluckman, P.D. Sequential patterns of inhibin subunit gene expression following hypoxic-ischemic injury in the rat brain. Neuroscience 1996, 70, 1013-1024. [CrossRef]

137. Lai, M.; Gluckman, P.; Dragunow, M.; Hughes, P.E. Focal brain injury increases activin betaA mRNA expression in hippocampal neurons. Neuroreport 1997, 8, 2691-2694. [CrossRef] [PubMed]

138. Johnson, E.J.; McDonald, K.; Caldarella, S.M.; Chung, H.Y.; Troen, A.M.; Snodderly, D.M. Cognitive findings of an exploratory trial of docosahexaenoic acid and lutein supplementation in older women. Nutr. Neurosci. 2008, 11, 75-83. [CrossRef] [PubMed]

139. Power, R.; Coen, R.F.; Beatty, S.; Mulcahy, R.; Moran, R.; Stack, J.; Howard, A.N.; Nolan, J.M. Supplemental retinal carotenoids enhance memory in healthy individuals with low levels of macular pigment in a randomized, double-blind, placebo-controlled clinical trial. J. Alzheimer's Dis 2018, 61, 947-961. [CrossRef] [PubMed]

140. Renzi-Hammond, L.M.; Bovier, E.R.; Fletcher, L.M.; Miller, L.S.; Mewborn, C.M.; Lindbergh, C.A.; Baxter, J.H.; Hammond, B.R. Effects of a lutein and zeaxanthin intervention on cognitive function: A randomized, double-masked, placebo-controlled trial of younger healthy adults. Nutrients 2017, 9, 1246. [CrossRef] [PubMed]

141. Lindbergh, C.A.; Renzi-Hammond, L.M.; Hammond, B.R.; Terry, D.P.; Mewborn, C.M.; Puente, A.N.; Miller, L.S. Lutein and zeaxanthin influence brain function in older adults: A randomized controlled trial. J. Int. Neuropsychol. Soc. 2018, 24, 77-90. [CrossRef] [PubMed]

142. Lindbergh, C.A.; Mewborn, C.M.; Hammond, B.R.; Renzi-Hammond, L.M.; Curran-Celentano, J.M.; Miller, L.S. Relationship of lutein and zeaxanthin levels to neurocognitive functioning: An fMRI study of older adults. J. Int. Neuropsychol. Soc. 2017, 23, 11-22. [CrossRef] [PubMed]

143. Feeney, J.; Finucane, C.; Savva, G.M.; Cronin, H.; Beatty, S.; Nolan, J.M.; Kenny, R.A. Low macular pigment optical density is associated with lower cognitive performance in a large, population-based sample of older adults. Neurobiol. Aging 2013, 34, 2449-2456. [CrossRef] [PubMed]

144. Vishwanathan, R.; Iannaccone, A.; Scott, T.M.; Kritchevsky, S.B.; Jennings, B.J.; Carboni, G.; Forma, G.; Satterfield, S.; Harris, T.; Johnson, K.C.; et al. Macular pigment optical density is related to cognitive function in older people. Age Ageing 2014, 43, 271-275. [CrossRef] [PubMed]

145. Kuchan, M.; Wang, F.; Geng, Y.; Feng, B.; Lai, C. Lutein stimulates the differentiation of human stem cells to neural progenitor cells in vitro. In Advances and Controversies in Clinical Nutrition; Abstract No. 23; ILSI North America: Washington, DC, USA, 2013. 
146. Nataraj, J.; Manivasagam, T.; Thenmozhi, A.J.; Essa, M.M. Lutein protects dopaminergic neurons against MPTP-induced apoptotic death and motor dysfunction by ameliorating mitochondrial disruption and oxidative stress. Nutr. Neurosci. 2016, 19, 237-246. [CrossRef] [PubMed]

147. Morris, M.C.; Wang, Y.; Barnes, L.L.; Bennett, D.A.; Dawson-Hughes, B.; Booth, S.L. Nutrients and bioactives in green leafy vegetables and cognitive decline: Prospective study. Neurology 2018, 90, e214-e222. [CrossRef] [PubMed]

148. Chew, E.Y.; Clemons, T.E.; Agrón, E.; Launer, L.J.; Grodstein, F.; Bernstein, P.S.; Age-Related Eye Disease Study 2 (AREDS2) Research Group. Effect of omega-3 fatty acids, lutein/zeaxanthin, or other nutrient supplementation on cognitive function: The AREDS2 randomized clinical trial. JAMA 2015, 314, 791-801. [CrossRef] [PubMed]

149. Libby, P.; Tabas, I.; Fredman, G.; Fisher, E.A. Inflammation and its resolution as determinants of acute coronary syndromes. Circ. Res. 2014, 114, 1867-1879. [CrossRef] [PubMed]

150. Kim, J.E.; Leite, J.O.; DeOgburn, R.; Smyth, J.A.; Clark, R.M.; Fernandez, M.L. A lutein-enriched diet prevents cholesterol accumulation and decreases oxidized LDL and inflammatory cytokines in the aorta of guinea pigs. J. Nutr. 2011, 141, 1458-1463. [CrossRef] [PubMed]

151. Han, H.; Cui, W.; Wang, L.; Xiong, Y.; Liu, L.; Sun, X.; Hao, L. Lutein prevents high fat diet-induced atherosclerosis in ApoE-deficient mice by inhibiting NADPH oxidase and increasing PPAR expression. Lipids 2015, 50, 261-273. [CrossRef] [PubMed]

152. Wang, S.; Wang, M.; Zhang, S.; Zhao, L. Oxidative stress in rats with hyperhomo-cysteinemia and intervention effect of lutein. Eur. Rev. Med. Pharmacol. Sci. 2014, 18, 359-364. [PubMed]

153. Boushey, C.J.; Beresford, S.A.; Omenn, G.S.; Motulsky, A.G. A quantitative assessment of plasma homocysteine as a risk factor for vascular disease. Probable benefits of increasing folic acid intakes. JAMA 1995, 274, 1049-1057. [CrossRef] [PubMed]

154. Homocysteine Studies Collaboration. Homocysteine and risk of ischemic heart disease and stroke: A meta-analysis. JAMA 2002, 288, 2015-2022. [CrossRef]

155. Sharavana, G.; Joseph, G.S.; Baskaran, V. Lutein attenuates oxidative stress markers and ameliorates glucose homeostasis through polyol pathway in heart and kidney of STZ-induced hyperglycemic rat model. Eur. J. Nutr. 2017, 56, 2475-2485. [CrossRef] [PubMed]

156. Lind, M.; Hayes, A.; Caprnda, M.; Petrovic, D.; Rodrigo, L.; Kruzliak, P.; Zulli, A. Inducible nitric oxide synthase: Good or bad? Biomed. Pharmacother. 2017, 93, 370-375. [CrossRef] [PubMed]

157. Howard, A.N.; Thurnham, D.I. Lutein and atherosclerosis: Belfast versus Toulouse revisited. Med. Hypotheses 2017, 98, 63-68. [CrossRef] [PubMed]

158. Tian, Y.; Kijlstra, A.; van der Veen, R.L.; Makridaki, M.; Murray, I.J.; Berendschot, T.T. The effect of lutein supplementation on blood plasma levels of complement factor D, C5a and C3d. PLoS ONE 2013, 8, e73387. [CrossRef] [PubMed]

159. Vlaicu, S.I.; Tatomir, A.; Rus, V.; Mekala, A.P.; Mircea, P.A.; Niculescu, F.; Rus, H. The role of complement activation in atherogenesis: The first 40 years. Immunol. Res. 2016, 64, 1-13. [CrossRef] [PubMed]

160. Wang, M.X.; Jiao, J.H.; Li, Z.Y.; Liu, R.R.; Shi, Q.; Ma, L. Lutein supplementation reduces plasma lipid peroxidation and C-reactive protein in healthy nonsmokers. Atherosclerosis 2013, 227, 380-385. [CrossRef] [PubMed]

161. Karppi, J.; Nurmi, T.; Kurl, S.; Rissanen, T.H.; Nyyssönen, K. Lycopene, lutein and beta-carotene as determinants of LDL conjugated dienes in serum. Atherosclerosis 2010, 209, 565-572. [CrossRef] [PubMed]

162. Karppi, J.; Kurl, S.; Mäkikallio, T.H.; Ronkainen, K.; Laukkanen, J.A. Low levels of plasma carotenoids are associated with an increased risk of atrial fibrillation. Eur. J. Epidemiol. 2013, 28, 45-53. [CrossRef] [PubMed]

163. Xu, X.R.; Zou, Z.Y.; Xiao, X.; Huang, Y.M.; Wang, X.; Lin, X.M. Effects of lutein supplement on serum inflammatory cytokines, ApoE and lipid profiles in early atherosclerosis population. J. Atheroscler. Thromb. 2013, 20, 170-177. [CrossRef] [PubMed]

164. Zou, Z.Y.; Xu, X.R.; Lin, X.M.; Zhang, H.B.; Xiao, X.; Ouyang, L.; Huang, Y.M.; Wang, X.; Liu, Y.Q. Effects of lutein and lycopene on carotid intima-media thickness in Chinese subjects with subclinical atherosclerosis: A randomised, double-blind, placebo-controlled trial. Br. J. Nutr. 2014, 111, 474-480. [CrossRef] [PubMed]

165. Polak, J.F.; Pencina, M.J.; Pencina, K.M.; O’Donnell, C.J.; Wolf, P.A.; D’Agostino Sr, R.B. Carotid-wall intima-media thickness and cardiovascular events. N. Engl. J. Med. 2011, 365, 213-221. [CrossRef] [PubMed] 
166. Sen, A.; Marsche, G.; Freudenberger, P.; Schallert, M.; Toeglhofer, A.M.; Nagl, C.; Schmidt, R.; Launer, L.J.; Schmidt, H. Association between higher plasma lutein, zeaxanthin, and vitamin $\mathrm{C}$ concentrations and longer telomere length: Results of the Austrian Stroke Prevention Study. J. Am. Geriatr. Soc. 2014, 62, 222-229. [CrossRef] [PubMed]

167. Brouilette, S.; Singh, R.K.; Thompson, J.R.; Goodall, A.H.; Samani, N.J. White cell telomere length and risk of premature myocardial infarction. Arterioscler. Thromb. Vasc. Biol. 2003, 23, 842-846. [CrossRef] [PubMed]

168. Bonds, D.E.; Harrington, M.; Worrall, B.B.; Bertoni, A.G.; Eaton, C.B.; Hsia, J.; Robinson, J.; Clemons, T.E.; Fine, L.J.; Chew, E.Y. Effect of long-chain $\omega-3$ fatty acids and lutein + zeaxanthin supplements on cardiovascular outcomes: Results of the Age-Related Eye Disease Study 2 (AREDS2) randomized clinical trial. JAMA Intern. Med. 2014, 174, 763-771. [CrossRef] [PubMed]

169. Leermakers, E.T.; Kiefte-de Jong, J.C.; Hofman, A.; Jaddoe, V.W.; Franco, O.H. Lutein intake at the age of 1 year and cardiometabolic health at the age of 6 years: The Generation R Study. Br. J. Nutr. 2015, 114, 970-978. [CrossRef] [PubMed]

170. Leermakers, E.T.; Darweesh, S.K.; Baena, C.P.; Moreira, E.M.; Melo van Lent, D.; Tielemans, M.J.; Muka, T.; Vitezova, A.; Chowdhury, R.; Bramer, W.M.; et al. The effects of lutein on cardiometabolic health across the life course: A systematic review and meta-analysis. Am. J. Clin. Nutr. 2016, 103, 481-494. [CrossRef] [PubMed]

171. Teymouri, M.; Pirro, M.; Fallarino, F.; Gargaro, M.; Sahebkar, A. IL-35, a hallmark of immune-regulation in cancer progression, chronic infections and inflammatory diseases. Int. J. Cancer 2018. [CrossRef] [PubMed]

172. Mantovani, A.; Barajon, I.; Garlanda, C. IL-1 and IL-1 regulatory pathways in cancer progression and therapy. Immunol. Rev. 2018, 281, 57-61. [CrossRef] [PubMed]

173. Jansen, R.J.; Robinson, D.P.; Stolzenberg-Solomon, R.Z.; Bamlet, W.R.; de Andrade, M.; Oberg, A.L.; Rabe, K.G.; Anderson, K.E.; Olson, J.E.; Sinha, R.; et al. Nutrients from fruit and vegetable consumption reduce the risk of pancreatic cancer. J. Gastrointest. Cancer 2013, 44, 152-161. [CrossRef] [PubMed]

174. Wang, L.; Li, B.; Pan, M.X.; Mo, X.F.; Chen, Y.M.; Zhang, C.X. Specific carotenoid intake is inversely associated with the risk of breast cancer among Chinese women. Br. J. Nutr. 2014, 111, 1686-1695. [CrossRef] [PubMed]

175. Bae, J.M. Reinterpretation of the results of a pooled analysis of dietary carotenoid intake and breast cancer risk by using the interval collapsing method. Epidemiol. Health 2016, 38, e2016024. [CrossRef] [PubMed]

176. Bakker, M.F.; Peeters, P.H.; Klaasen, V.M.; Bueno-de-Mesquita, H.B.; Jansen, E.H.; Ros, M.M.; Travier, N.; Olsen, A.; Tjønneland, A.; Overvad, K.; et al. Plasma carotenoids, vitamin C, tocopherols, and retinol and the risk of breast cancer in the European Prospective Investigation into Cancer and Nutrition cohort. Am. J. Clin. Nutr. 2016, 103, 454-464. [CrossRef] [PubMed]

177. Leoncini, E.; Edefonti, V.; Hashibe, M.; Parpinel, M.; Cadoni, G.; Ferraroni, M.; Serraino, D.; Matsuo, K.; Olshan, A.F.; Zevallos, J.P.; et al. Carotenoid intake and head and neck cancer: A pooled analysis in the International Head and Neck Cancer Epidemiology Consortium. Eur. J. Epidemiol. 2016, 31, 369-383. [CrossRef] [PubMed]

178. Chen, F.; Hu, J.; Liu, P.; Li, J.; Wei, Z.; Liu, P. Carotenoid intake and risk of non-Hodgkin lymphoma: A systematic review and dose-response meta-analysis of observational studies. Ann. Hematol. 2017, 96, 957-965. [CrossRef] [PubMed]

179. Ge, X.X.; Xing, M.Y.; Yu, L.F.; Shen, P. Carotenoid intake and esophageal cancer risk: A meta-analysis. Asian Pac. J. Cancer Prev. 2013, 14, 1911-1918. [CrossRef] [PubMed]

180. Grudzinski, W.; Piet, M.; Luchowski, R.; Reszczynska, E.; Welc, R.; Paduch, R.; Gruszecki, W.I. Different molecular organization of two carotenoids, lutein and zeaxanthin, in human colon epithelial cells and colon adenocarcinoma cells. Spectrochim. Acta A Mol. Biomol. Spectrosc. 2018, 188, 57-63. [CrossRef] [PubMed]

181. Chen, J.; Jiang, W.; Shao, L.; Zhong, D.; Wu, Y.; Cai, J. Association between intake of antioxidants and pancreatic cancer risk: A meta-analysis. Int. J. Food Sci. Nutr. 2016, 67, 744-753. [CrossRef] [PubMed]

182. Zhou, Y.; Wang, T.; Meng, Q.; Zhai, S. Association of carotenoids with risk of gastric cancer: A meta-analysis. Clin. Nutr. 2016, 35, 109-116. [CrossRef] [PubMed]

183. Ho, W.J.; Simon, M.S.; Yildiz, V.O.; Shikany, J.M.; Kato, I.; Beebe-Dimmer, J.L.; Cetnar, J.P.; Bock, C.H. Antioxidant micronutrients and the risk of renal cell carcinoma in the Women's Health Initiative cohort. Cancer 2015, 121, 580-588. [CrossRef] [PubMed] 
184. Huang, J.; Lu, M.S.; Fang, Y.J.; Xu, M.; Huang, W.Q.; Pan, Z.Z.; Chen, Y.M.; Zhang, C.X. Serum carotenoids and colorectal cancer risk: A case-control study in Guangdong, China. Mol. Nutr. Food Res. 2017, 61. [CrossRef] [PubMed]

185. Qiu, X.; Gao, D.H.; Xiang, X.; Xiong, Y.F.; Zhu, T.S.; Liu, L.G.; Sun, X.F.; Hao, L.P. Ameliorative effects of lutein on non-alcoholic fatty liver disease in rats. World J. Gastroenterol. 2015, 21, 8061-8072. [CrossRef] [PubMed]

186. Melo van Lent, D.; Leermakers, E.T.M.; Darweesh, S.K.L.; Moreira, E.M.; Tielemans, M.J.; Muka, T.; Vitezova, A.; Chowdhury, R.; Bramer, W.M.; Brusselle, G.G.; et al. The effects of lutein on respiratory health across the life course: A systematic review. Clin. Nutr. ESPEN 2016, 13, e1-e7. [CrossRef] [PubMed]

187. Bliuc, D.; Nguyen, N.D.; Alarkawi, D.; Nguyen, T.V.; Eisman, J.A.; Center, J.R. Accelerated bone loss and increased post-fracture mortality in elderly women and men. Osteoporos. Int. 2015, 26, 1331-1339. [CrossRef] [PubMed]

188. Takeda, H.; Tominari, T.; Hirata, M.; Watanabe, K.; Matsumoto, C.; Grundler, F.M.W.; Inada, M.; Miyaura, C. Lutein Enhances Bone Mass by Stimulating Bone Formation and Suppressing Bone Resorption in Growing Mice. Biol. Pharm. Bull. 2017, 40, 716-721. [CrossRef] [PubMed]

189. Tominari, T.; Matsumoto, C.; Watanabe, K.; Hirata, M.; Grundler, F.M.; Inada, M.; Miyaura, C. Lutein, a carotenoid, suppresses osteoclastic bone resorption and stimulates bone formation in cultures. Biosci. Biotechnol. Biochem. 2017, 81, 302-306. [CrossRef] [PubMed]

190. Hayhoe, R.P.G.; Lentjes, M.A.H.; Mulligan, A.A.; Luben, R.N.; Khaw, K.T.; Welch, A.A. Carotenoid dietary intakes and plasma concentrations are associated with heel bone ultrasound attenuation and osteoporotic fracture risk in the European Prospective Investigation into Cancer and Nutrition (EPIC)-Norfolk cohort. Br. J. Nutr. 2017, 117, 1439-1453. [CrossRef] [PubMed]

191. Grether-Beck, S.; Marini, A.; Jaenicke, T.; Stahl, W.; Krutmann, J. Molecular evidence that oral supplementation with lycopene or lutein protects human skin against ultraviolet radiation: Results from a double-blinded, placebo-controlled, crossover study. Br. J. Dermatol. 2017, 176, 1231-1240. [CrossRef] [PubMed]

192. Palombo, P.; Fabrizi, G.; Ruocco, V.; Ruocco, E.; Fluhr, J.; Roberts, R.; Morganti, P. Beneficial long-term effects of combined oral/topical antioxidant treatment with the carotenoids lutein and zeaxanthin on human skin: A double-blind, placebo-controlled study. Skin Pharmacol. Physiol. 2007, 20, 199-210. [CrossRef] [PubMed]

193. Morganti, P.; Bruno, C.; Guarneri, F.; Cardillo, A.; Del Ciotto, P.; Valenzano, F. Role of topical and nutritional supplement to modify the oxidative stress. Int. J. Cosmet. Sci. 2002, 24, 331-339. [CrossRef] [PubMed]

194. Lorenzoni, F.; Giampietri, M.; Ferri, G.; Lunardi, S.; Madrigali, V.; Battini, L.; Boldrini, A.; Ghirri, P. Lutein administration to pregnant women with gestational diabetes mellitus is associated to a decrease of oxidative stress in newborns. Gynecol. Endocrinol. 2013, 29, 901-903. [CrossRef] [PubMed]

195. Cohen, J.M.; Kramer, M.S.; Platt, R.W.; Basso, O.; Evans, R.W.; Kahn, S.R. The association between maternal antioxidant levels in midpregnancy and preeclampsia. Am. J. Obstet. Gynecol. 2015, 213, 695.e1-13. [CrossRef] [PubMed]

196. Zielińska, M.A.; Wesołowska, A.; Pawlus, B.; Hamułka, J. Health effects of carotenoids during pregnancy and lactation. Nutrients 2017, 9, 838. [CrossRef] [PubMed]

197. European Food Safety Authority. Scientific opinion on the re-evaluation of lutein [e 161b] as a food additive. EFSA J. 2010, 8, 1678. [CrossRef]

198. Harikumar, K.B.; Nimita, C.V.; Preethi, K.C.; Kuttan, R.; Deshpande, J. Toxicity profile of lutein and lutein ester isolated from marigold flowers (Tagetes erecta). Int. J. Toxicol. 2008, 27, 1-9. [CrossRef] [PubMed]

199. Ravikrishnan, R.; Rusia, S.; Ilamurugan, G.; Salunkhe, U.; Deshpande, J.; Shankaranarayanan, J.; Shankaranarayana, M.L.; Soni, M.G. Safety assessment of lutein and zeaxanthin (Lutemax 2020): Subchronic toxicity and mutagenicity studies. Food Chem. Toxicol. 2011, 49, 2841-2848. [CrossRef] [PubMed]

200. Amengual, J.; Lobo, G.P.; Golczak, M.; Li, H.N.; Klimova, T.; Hoppel, C.L.; Wyss, A.; Palczewski, K.; von Lintig, J. A mitochondrial enzyme degrades carotenoids and protects against oxidative stress. FASEB J. 2011, 25, 948-959. [CrossRef] [PubMed]

201. Institute of Medicine (US) Panel on Dietary Antioxidants and Related Compounds. Dietary Reference Intakes for Vitamin C, Vitamin E, Selenium, and Carotenoids; National Academies Press (US): Washington, DC, USA, 2000.

202. Joint, F.A.O. Evaluation of Certain Food Additives: Sixty-Third Report of the Joint FAO/WHO Expert Committee on Food Additives; World Health Organization: Geneva, Switzerland, 2005; pp. 23-26. 
203. Landrum, J.T.; Bone, R.A.; Joa, H.; Kilburn, M.D.; Moore, L.L.; Sprague, K.E. A one year study of the macular pigment: The effect of 140 days of a lutein supplement. Exp. Eye Res. 1997, 65, 57-62. [CrossRef] [PubMed]

204. Dagnelie, G.; Zorge, I.S.; McDonald, T.M. Lutein improves visual function in some patients with retinal degeneration: A pilot study via the Internet. Optometry 2000, 71, 147-164. [PubMed]

205. European Food Safety Authority (EFSA). Safety, bioavailability and suitability of lutein for the particular nutritional use by infants and young children-Scientific Opinion of the Panel on Dietetic Products, Nutrition and Allergies. EFSA J. 2008, 823, 1-24.

206. Zheng, Y.F.; Bae, S.H.; Kwon, M.J.; Park, J.B.; Choi, H.D.; Shin, W.G.; Bae, S.K. Inhibitory effects of astaxanthin, b-cryptoxanthin, canthaxanthin, lutein, and zeaxanthin on cytochrome P450 enzyme activities. Food Chem. Toxicol. 2013, 59, 78-85. [CrossRef] [PubMed]

207. Olmedilla, B.; Granado, F.; Southon, S.; Wright, A.J.; Blanco, I.; Gil-Martinez, E.; van den Berg, H.; Thurnham, D.; Corridan, B.; Chopra, M.; et al. A European multicentre, placebo-controlled supplementation study with alpha-tocopherol, carotene-rich palm oil, lutein or lycopene: Analysis of serum responses. Clin. Sci. 2002, 102, 447-456. [CrossRef] [PubMed]

208. Satia, J.A.; Littman, A.; Slatore, C.G.; Galanko, J.A.; White, E. Long-term use of beta-carotene, retinol, lycopene, and lutein supplements and lung cancer risk: Results from the Vitamins and Lifestyle (VITAL) study. Am. J. Epidemiol. 2009, 169, 815-828, Erratum in Am. J. Epidemiol. 2009, 169, 1409. [CrossRef] [PubMed]

209. Choi, R.Y.; Chortkoff, S.C.; Gorusupudi, A.; Bernstein, P.S. Crystalline maculopathy associated with high-dose lutein supplementation. JAMA Ophthalmol. 2016, 134, 1445-1448. [CrossRef] [PubMed]

(C) 2018 by the authors. Licensee MDPI, Basel, Switzerland. This article is an open access article distributed under the terms and conditions of the Creative Commons Attribution (CC BY) license (http:/ / creativecommons.org/licenses/by/4.0/). 